\title{
Sosyal Değer Yönelimi ve Sosyal İkilemlerde İş Birliği: Düzenleyici Odağın ve Tanımlayıcı Normların Etkisi
}

\section{Social Value Orientation and Cooperation in Social Dilemmas: The Effects of Regulatory Focus and Descriptive Norms}

\author{
Gökhan Karagonlar ${ }^{1}$ (]) Sevgi Emirza² ${ }^{\circledR}$
}

Yazar notu: Bu çalışma, TÜBITAK (proje no: 114K324) tarafından desteklenen ve Dr. Gökhan Karagonlar'ın yürütücülüğünü üstlendiği bilimsel bir proje kapsamında gerçekleştirilmiştir.

'Dr, Dokuz Eylül Üniversitesi, İşletme Fakültesi, İşletme Bölümü, İzmir-Türkiye ${ }^{2}$ Dr, Dokuz Eylül Üniversitesi, İşletme Fakültesi, Iş̧letme Bölümü, İzmir-Türkiye

ORCID: G.K. 0000-0002-2718-5258; S.E. 0000-0002-5988-8935

Sorumlu yazar/Corresponding author: Gökhan Karagonlar,

Dokuz Eylül Unniversity, Faculty of Business, Dokuz Eylül Üniversitesi İşletme Fakültesi Tınaztepe Yerleşkesi 35390 Buca İzmir Türkiye

E-posta/E-mail:

gokhan.karagonlar@deu.edu.tr

Başvuru/Submitted: 26.10 .2020 Revizyon Talebi/Revision Requested: 27.08.2021

Son Revizyon/Last Revision Received: 02.11 .2021

Kabul/Accepted: 17.11.2021

Citation/Atıf: Karagonlar, G. ve Emirza, S. (2021). Sosyal değer yönelimi ve sosyal ikilemlerde iş birliği: Düzenleyici odağın ve tanımlayıcı normların etkisi. Psikoloji Çalışmaları - Studies in Psychology, 41(3), 991-1035.

https://doi.org/10.26650/SP2020-816761
ÖZ

Sosyal ikilemler bireysel çıkar ile topluluk çıkarının çeliştiği durumlar olarak ifade edilir. Bu çalışma, sosyal ikilemler yazınındaki önemli sorulardan biri olan, sosyal ikilem durumlarında bireyleri topluluk çıkarını kollamaya (iş birliğine) yönelten faktörler nelerdir sorusuna katkıda bulunmayı amaçlamaktadır. $\mathrm{Bu}$ amaçla, düzenleyici odak ve normatif davranışın odağı teorileri ve sosyal değer yönelimleri alan yazınından yola çıkılarak bireylerin sosyal değer yönelimlerinin, düzenleyici odak ve tanımlayıcı normlar ile etkileşimli olarak iş birliği davranışını etkileyeceği öngörülmüştür. Çalışmanın hipotezleri bir devlet üniversitesinden 289 öğrenci üzerinde bir mahkumun ikilemi deneyi ile test edilmiştir. Sosyal değer yönelimleri deneyden üç hafta önce ölçülmüş, düzenleyici odak (önleme ve yükselme) ve tanımlayıcı normlar (kontrol, bencil davranış normu ve iş birliği normu) manipüle edilmiştir. Bulgular, beklenen sosyal değer yönelimi ve düzenleyici odak etkileşiminin yalnızca erkekler için anlamlı olduğunu göstermiştir. Buna göre, yükselme odağına kıyasla önleme odağı aktifleştirilmiş toplum yanlısı erkekler daha düşük iş birliği davranışı göstermektedir. Ayrıca, tanımlayıcı normun bencil davranışa kıyasla iş birliğini işaret ettiği durumda toplum yanlısı bireylerin iş birliği davranışı artmıştır. Üç yönlü sosyal değer yönelimi, düzenleyici odak ve tanımlayıcı norm etkileşimi ise anlamlı bulunmamıştır. Bulgular, toplum yanlısı bireylerin iş birliği davranışının incelenen durumsal faktörlerden etkilendiğini, kendine yanlıların iş birliği davranışının ise değişmediğini göstermektedir. Buna göre, topluluk çıkarını düşünen bireylerin yüksek iş birliğinin sağlanması için bu durumsal faktörler göz önüne alınmalıdır. Bu çalışma, düzenleyici odak ve normatif davranışın odağı teorileri ile sosyal değer yönelimleri yazınını bütünleştirerek bireylerin sosyal ikilem durumlarındaki tercihlerini anlamaya çalışması bakımından alan yazına özgün katkıda bulunmaktadır. Ayrıca, bu çalışma Türkiye'de sosyal ikilem durumlarında düşük iş birliği davranışı gösterilmesini en azından kısmen açıklayabilecek teorik bir model sınayarak pratik katkı da sağlamaktadır.

Anahtar Kelimeler: Sosyal değer yönelimi, iş birliği, düzenleyici odak, tanımlayıcı normlar 


\section{ABSTRACT}

Social dilemmas (SDs) refer to situations where self and collective interests conflict. This study aims to contribute to an important question in the SD literature: "what are the factors that lead individuals to protect the collective interests (to cooperate) in SDs?". Based on the regulatory focus theory, the focus theory of normative conduct, and the literature on social value orientation (SVO), it was hypothesized that SVO would interact with regulatory focus and descriptive norms to influence cooperation in a SD. Using a prisoner's dilemma game (PDG), hypotheses were tested on 289 participants from a public university. SVO was measured three weeks prior to the PDG, while regulatory focus (promotion vs. prevention) and descriptive norms (control vs. self-interest vs. cooperation) were manipulated during the experiment. Compared with promotion focus, prevention focus activation was observed to lead to lower cooperation among prosocial men. Moreover, prosocials had higher cooperation when descriptive norms signaled cooperative behavior rather than selfish behavior. SVO $x$ regulatory focus $x$ descriptive norms interaction was insignificant. These findings suggest that individuals with prosocial, but not with proself motivation, are influenced by these situational factors. Thus, policymakers should consider these factors to ensure the high cooperation of prosocial individuals. Integrating regulatory focus theory, focus theory of normative conduct, and the literature on SVO, this study makes a unique contribution to the literature as it attempts to enhance the understanding of the preferences of individuals in SDs. Furthermore, this study provides a practical contribution by testing a theoretical model that can at least partially explain the low cooperative behavior in SD situations in Turkey.

Keywords: Social value orientation, cooperation, regulatory focus, descriptive norms

\section{EXTENDED ABSTRACT}

Social dilemmas (SD) refer to situations where self-interest is at odds with collective interest and individuals are required to choose between the maximization of self-interests and the maximization of collective interests (Dawes, 1980; Kollock, 1998). An important factor influencing individuals' motivation for cooperation under SDs is their social value orientation (SVO, Bogaert, Boone, \& Decklerck, 2008; Messick \& McClintock, 1968). SVO is a stable personality trait that refers to the weights individuals assign to their self-interests and others' interests in the distribution of outcomes between self and others.

This study extends prior research in SVO in three ways. First, although SVO has been linked to cooperation in various SD experiments, a large body of this research measured SVO and cooperation simultaneously, potentially causing an inflated effect due to common method variance (Balliet, Parks, \& Joireman, 2009). To overcome this effect, this study examines the association of SVO measured weeks before with cooperation in SD tasks. Second, the SVO effect, i.e., prosocials' higher cooperation than proselfs, in SDs is examined under two conditions. Specifically, based on the regulatory focus theory (Higgins, 1997, 2012), it is predicted that prosocials' cooperation in a SD will be lower when they are primed with a prevention focus than with a promotion focus; nonetheless, regulatory focus is expected to have little effect on proselfs' cooperation $(H 1)$. Furthermore, based on the focus theory of normative conduct (Cialdini, Reno, \& Kallgren, 1990), it is hypothesized that prosocials' cooperation in a SD will depend on the salient descriptive norms in the situation, whereas proselfs' cooperativeness is less likely to be influenced by descriptive norms ( $H 2)$. Finally, 
integrating regulatory focus theory and focus theory of normative conduct, it is predicted that among prosocials, prevention-focused individuals will be more likely to be influenced by descriptive norms than promotion-focused individuals $(H 3)$.

\section{Method}

The hypotheses were tested on a sample of 289 students from various departments of a public university in Turkey. SVO was measured with the 12-item Ring measure (Liebrand, 1984). Of the 289 participants who participated in the actual experiment, 111 (38.4\%) were prosocial, 83 (28.7\%) were individualist and 95 (32.9\%) were competitor.

Participants took part in two independent rounds of PDG. In each round, participants were paired with ostensibly a different (fictituous) player selected from a vast pool of participants.

At the beginning of the second round, descriptive norm manipulation was performed. One-third of participants were assigned to the high cooperation norm condition, another one-third to the low cooperation norm condition, and the remaining one-third was assigned to the control condition. Following the manipulation, participants played the PDG for the second time with an ostensibly new person they were paired with from the participant pool. They were then asked to report their mood and answer the manipulation check questions. $H 1$ was tested using the amount of money participants sent to the other person in the first round (i.e., cooperation in the first round), whereas $\mathrm{H} 2$ and $\mathrm{H} 3$ were tested using participants' cooperation in the second round.

\section{Results}

Hypotheses were tested using multiple regression procedure. Contrary to expectations, SVO $x$ regulatory focus interaction effect was insignificant $(\beta=-.02, p=.55)$. However, SVO $x$ regulatory focus $x$ gender interaction was significant $(\beta=.11, p<.01 ; \Delta R 2=.03)$, and the two-way interactions between males and females revealed that SVO $x$ regulatory focus interaction was significant among males $(B=-.13, S E=.05, p<.05)$, but not among females $(B=.10, S E=.06, p=.11)$. Simple slopes analysis for the significant two-way interaction revealed that among highly prosocial men, prevention focus reduced cooperation compared with promotion focus $(B=-8.22, S E=2.94, p<.01)$. However, for low prosocial men (or proselfs) regulatory focus did not affect cooperation $(B=1.83, S E=2.82, p=.52$ ). These findings support $\mathrm{H} 1$ only for men.

In support of $H 2$, among highly prosocial participants (1 SD above the mean SVO angle) cooperative descriptive norms led to higher cooperation than descriptive norms signaling 
self-interested behavior ( $B=12.93, S E=3.25, p<.01)$. Among relatively proself participants (1 SD below the mean SVO angle), cooperation was not different in the two descriptive norm conditions $(B=1.57, S E=3.35, p=.61)$. These findings support $H 2$. Finally, SVO $x$ Regulatory focus $x$ norm 1 three-way interaction effect was insignificant. Thus, $H 3$ was not supported.

\section{Discussion}

The current study tested the interaction effects of SVO, regulatory focus, and descriptive norms on cooperation in a PDG. Accordingly, for men with prosocial motivation, compared with promotion focus, prevention focus activation decreased cooperation. However, for those with proself motivation, regulatory focus manipulation did not affect cooperation decisions. Moreover, the saliency of descriptive norms emphasizing cooperation over selfishness led to higher cooperation levels among prosocials, but not proselfs. Nevertheless, no support was found for the three-way interaction effect of SVO, regulatory focus, and descriptive norm, which indicates that the effect of descriptive norms on cooperation decision of prosocials is independent of regulatory focus. 
Alan yazına ilk kez Dawes (1980) tarafindan kazandırılan sosyal ikilemler terimi en az iki kişilik bir toplulukta bireylerin kendi çıkarlarını veya topluluğun çıkarlarını maksimize etmek arasında bir seçim yapması gereken durumları temsil etmektedir. Sosyal ikilemlerde, her bireyin elde edeceği bireysel kazanım bireylerin kendi seçimlerinin yanı sıra topluluktaki diğer birey(ler)in seçimlerine de bağlıdır. Diğer bir deyişle, topluluğu oluşturan bireyler arasında karşılıklı sosyal bağımlılık (social interdependence; Kelley ve Thibaut, 1978) durumu mevcuttur. Değişik karşılıklı bağımlılık yapıları (örn., tutsak/mahkum ikilemi, tavuk ikilemi, güvence ikilemi) ile karşımıza çıkabilen sosyal ikilemlerin en temel özelliği (genelde kısa vadeli) bireysel çıkarlar ile (genelde uzun vadeli) topluluk çıkarlarının birbiriyle çelişmesidir (Kollock, 1998). Bireylerin kendi çıkarlarının peşinden koşması topluluğun çıkarı için çalışmasına kıyasla daha fazla bireysel fayda sağlayacaktır. Ancak bunun cazibesiyle tüm bireyler kendi bireysel çıkarlar1 doğrultusunda hareket ederse elde edecekleri bireysel fayda, topluluğun çıkarı doğrultusunda hareket etmeleri, diğer bir değişle iş birliği yapmaları durumunda elde edecekleri bireysel faydadan daha az olacaktır (Dawes, 1980; Van Lange, Joireman, Parks ve Van Dijk, 2013). Dolayısıyla tüm bireylerin aynı anda kişisel çıkarlarının peşinden koşması topluluğun (ve dolayısıyla topluluğu oluşturan bireylerin) refahına zarar verecektir. Herkesin kullanımına açık olan kamusal kaynakların ve alanların (common resource; örn., su kaynakları, otlaklar) aşırı kullanımı veya ihtiyaç halinde tüm bireylerin yararlanabileceği kamusal mallara (public goods; örn., kan bankası, eğitim) gönüllü katkı yapmama sosyal ikilem durumlarında bencil davranışı ifade eden durumlara örnek olarak gösterilebilir.

Sosyal ikilemlerin hayatın her alanında karşımıza çıkması ve bireylerin bencil davranışlarının gruplara, örgütlere ve topluma kaynak israfı bakımından önemli zararlar vermesi farklı disiplinlerden araştırmacıları bu konuya yönlendirmiştir. Sosyal ikilem durumlarında bireyleri kişisel çıkarlarını bir kenara bırakıp topluluk çıkarlarını maksimize etmek için hareket etmeye, kısacası iş birliği davranışına yönelten faktörleri ortaya çıkarmak önem arz etmektedir. Bu konuda yapılan araştırmaların temel konusu/amacı birbirini tanımayan bireylerden oluşan ve genelde kısa süreli anonim etkileşimlerde bulunan topluluklarda bireyler arasındaki iş birliği davranışını etkileyen faktörleri ortaya çıkarmak olmuştur (Bkz. Bogaert, Boone ve Declerck, 2008; Cooper ve ark., 1996; Parks, Joireman, Van Lange, 2013). Bunun sebebi toplumsal, ekonomik ve teknolojik gelişmelerin etkisiyle birbirlerine yabancı bireyler arasındaki (genelde kısa süreli) ano- 
nim etkileşimlerin toplumlarda her geçen gün artması ve iş birliğini sağlamanın en zor olduğu koşulların bunlar olmasıdır (Nowak ve Sigmund, 2005). Şaşırtıcı bir şekilde, sosyal ikilemler konusunun önemine rağmen ülkemizde bu konu üzerine gerçekleştirilen sosyal psikoloji çalışması yok denecek kadar azdır. Örneğin, yakın dönemde yürütülen bir araştırmada ergenlerin ve genç yetişkinlerin sosyal değer yönelimlerinin bazı olumlu sosyal ve rekabetçi davranışlara dair tutum ve eğilimlerini etkileyebileceği gösterilmiştir (Yaban, 2017). Bahsi geçen araştırmada bireylerin yardım etme gibi toplum yanlısı davranışlarda bulunma ya da rekabet etme gibi yönelimleri özbildirim yoluyla ölçülmüştür. Ancak bireylerin davranışları ölçülmediği için sosyal değer yönelimlerinin muhtemel bir sosyal ikilem durumunda iş birliği davranışlarını ne yönde etkileyeceği konusunda söz konusu araştırma bir fikir sunmamaktadır. Dahası, Türkiye'den veri toplanan sınırlı sayıdaki yabancı kaynaklı çalışmada Türk örneklemlerinin batı örneklemlerine kıyasla sosyal ikilem durumlarında iş birliği yapmaya daha az yöneldiğinin görülmesi (Bkz. Herrmann, Thöni ve Gächter, 2008), ülkemiz açısından sosyal ikilemlerde iş birliği davranışını etkileyen faktörleri ortaya çıkarmanın önemini daha da arttırmaktadır.

Sosyal ikilem durumlarında bireylerin bencil davranmasını ya da topluluk çıkarını gözetmesini açıklayan iki temel teori, hedef-beklenti (Pruitt ve Kimell, 1977) ve karş1lıklı sosyal bağımlılık (Kelley ve Thibaut, 1978; Van Lange ve Rusbult, 2012) teorileridir. Bu teorilere göre bireylerin iş birliği davranışı göstermesi, bireyin bu yönde bir hedefi/güdüsü olması ve bireyin topluluktaki diğer kişilerin de bu yönde davranacağına dair beklentisi olması şeklinde iki koşula bağlıdır. Sosyal ikilemlerde bireylerin hedeflerini belirleyen faktörlerden biri sosyal değer yönelimidir (Social Value Orientation; Bogaert ve ark., 2008, Messick ve McClintock, 1968). Sosyal değer yönelimi çıktıların, bireyin kendisi ve diğer bireyler arasındaki dă̆llımına ilişkin kişilerin sabit tercihleri olarak tanımlanır (Messick ve McClintock, 1968, s. 2). Çalışmalar, sosyal değer yöneliminin sosyal ikilemlerde birey davranışını etkilediğini ve toplum yanlısı (prosocial) bireylerin kendine yanlılara (proself) nazaran daha fazla iş birliği davranışında bulunduğunu göstermektedir (bir meta-analiz çalışması için Bkz. Balliet, Parks ve Joireman, 2009).

Bu çalışmanın odağını oluşturan sosyal ikilem durumlarında gösterilen iş birliği davranışı alan yazında toplum yanlısı davranış (prosocial behavior) konusu altında incelenmektedir. Daha ayrıntılı ifade etmek gerekirse, iş birliği davranışı birkaç farklı türü 
bulunan toplum yanlısı davranışın özel bir formudur (Eisenberg ve Fabes, 1998). İş birliği davranışı iki veya daha fazla kişinin birbirinin eşiti partnerler olarak bir araya geldiği ve tüm tarafların fayda göreceği ortak bir amaç için karşılıklı bağımlılık içerisinde çalıştıkları durumu ifade etmektedir (Penner, Dovidio, Piliavin ve Schroeder, 2005). Toplum yanlısı davranış ise genel olarak bireyin bir başkasının faydasını gözeterek yaptığı gönüllü davranışların tümünü kapsamaktadır (Eisenberg ve Fabes, 1998). İş birliği davranışı dışında yardım etme (Maner ve ark., 2002), gönüllülük (Omoto ve Snyder, 2002) ve özgecilik (Piliavin ve Charng, 1990) de diğer toplum yanlısı davranışlar olarak sayılabilir.

Psikoloji alanında toplum yanlısı davranış üzerindeki araştırmalar dönemsel olarak farklı açılardan gelişmiştir. 1960-1980 arasında, araştırmalar ağırlıklı olarak bireylerin acil ve acil olmayan durumlarda ne zaman toplum yanlısı davranış gösterdiğini incelemişlerdir. Örneğin bu dönemde, Latané ve Darley’nin (1970) seyirci kalma etkisine ilişkin karar modeli, bireyin nihai yardım etme kararının, durumun ne derece yardım gerektirdiği, bireyin kişisel sorumluluk alma isteği ve nasıl yardım edilmesi gerektiği gibi bir dizi ön karara bağlı olduğunu savunmuştur. Yine bu dönemde, maliyet-ödül yaklaşımı (Piliavin, Dovidio, Gaertner ve Clark, 1981) yardım etme davranışını açıklamak için bireylerin ödül ve maliyet hesabı yaptıklarını ve bu hesaba göre net maliyetin en az olmasını sağlayacak şekilde bir karara vardıklarını iddia etmiştir. 1980’ler ve 1990'lar döneminde ise araştırmalar ağırlıklı olarak bireylerin neden ve hangi motivasyonel süreçler ile toplum yanlısı davranışlar gösterdiğini anlamaya çalışmışlardır. Buna göre, bir grup araştırmacı edimsel koşullanma ve sosyal öğrenme ilkelerini kullanarak toplum yanlısı davranışın sosyalleşme süreçleri (Staub, 2002) ve gelişimsel faktörler (Eisenberg ve Fabes, 1991) tarafından şekillendiğini ileri sürmüşlerdir. Diğer bir grup araştırmacı ise sosyal ve kişisel standartlara odaklanarak sosyal sorumluluk ve karşılıklılık gibi normların (Dovidio, 1984), olumlu benlik algısı sürdürme amacının (Schwartz ve Howard, 1982) ve kişisel ihtiyaçları karşılama isteğinin (Omoto ve Snyder, 1995) bireyleri toplum yanlısı davranışlar göstermeye yönlendirebileceğini belirtmişlerdir. Son olarak bu dönemde uyarılma ve duygulanım süreçlerini inceleyen bir grup çalışma sempati ve şefkat gibi empatik duyguların ya da suçluluk ve üzüntü gibi olumsuz duyguların bireyleri toplum yanlısı davranış için harekete geçirebileceğini savunmuştur (Batson, 1991). Alandaki en güncel çalışmalar ise toplum yanlısı davranışı açıklayabilecek bilinçdışı süreçleri ve gruplar arası etkileri incelemişlerdir. Örneğin, araştırmalar 
ortak grup kimliği oluşturulan bireylere karşı gösterilen toplum yanlısı davranışın arttığını (Gaertner ve ark., 1999) ya da bilinçdışı hazırlama (priming) ile daha fazla mimik gösterilen bireylerin yardım etme eğiliminin arttığını (van Baaren, Holland, Kawakami ve van Knippenberg, 2004) ortaya koymuşlardır.

Bu alanda Türkiye'de yürütülen çalışmalara bakıldığında gerek genel olarak toplum yanlısı davranışları gerekse özel olarak iş birliği davranışını inceleyen araştırmaların ağırlıklı olarak gelişim psikolojisi (Aydın, 2021), örgütsel psikoloji (Yener, 2017; Yeşiltaş, Kanten ve Sormaz, 2013) ya da eğitim psikolojisi (Çalık, Özbay, Özer, Kurt ve Kandemir, 2009) alanlarında yoğunlaştığı görülmektedir. Gelişim psikolojisi ve eğitim bilimleri alanlarındaki çalışmalar, okul öncesi ya da okulda eğitim gören çocukların toplum yanlısı davranışlarını ve bu davranışa etki eden faktörleri incelerken, örgütsel psikoloji alanındaki araştırmalar çalışanların örgüt içinde gösterdikleri toplum yanlısı davranışları belirleyen öncülleri ortaya koymayı amaçlamışlardır. Ancak, Türkiye'de yetişkin örnekleminde, özel bir toplum yanlısı davranış olan sosyal ikilem durumundaki iş birliği davranışının düşük olduğu bulgularına karşın (Herrmann ve ark., 2008), bu iş birliği davranışını arttıracak faktörler yeteri kadar bilinmemektedir.

$\mathrm{Bu}$ çalışma mevcut yazına iki şekilde katkıda bulunmaktadır. Çalışma ilk olarak, sosyal değer yönelimlerini üç hafta önce ölçümleyerek sosyal değer yönelimlerinin bireyin sosyal ikilemlerdeki iş birliği davranışı üzerindeki olası etkilerini görmeyi amaçlamaktadır. Geçmiş çalı̧̧maların çok büyük bir bölümü sosyal değer yönelimi ve iş birliği davranışının ölçümlemesini aynı zamanda yapmıştır ve bulgular ortak yöntem-ortak kaynak (common method-common source) varyansının etkilerini de taşımaktadır (Bkz. Balliet ve ark., 2009). Bu çalışma ise bu etkileri minimize ederek değer yönelimlerinin gerçek etkisini görebilmeye katkı sunmaktadır. Diğer taraftan, toplum yanlısı bireylerin iş birliği davranışı göstermesi koşulsuz olmayıp, topluluktaki diğer bireylerin de iş birliği davranışı göstermesine, bireyin iş birliği davranışının diğerleri tarafından sömürülmeyeceği beklentisine bağlıdır (Bogaert ve ark., 2008). Sosyal ikilem durumlarında bencil davranışın azımsanmayacak bir kısmı aslında toplum yanlısı yönelime sahip olan ancak diğerleri tarafindan sömürülme korkusu yaşayan bireylerce gerçekleştirilmektedir (Balliet ve Van Lange, 2013). Buna paralel olarak, Pletzer ve arkadaşları (2018) toplum yanlısı bireylerin iş birliği davranışının arttırılması için bu bireylerin beklentilerini etkileyebilecek faktörlerin incelenmesi gerekliliğine işaret etmektedir. Bu doğrultuda, bu çalışmada düzenleyici odak (Higgins, 1997; 2012) ve 
normatif davranışın odağı (Focus theory of normative conduct; Cialdini, Reno ve Kallgren, 1990) teorilerinin bireylerin beklentilerini/algılarını yönlendirmesine dair öngörüleri 1şığında, durumsal olarak aktive edilmiş düzenleyici odağın ve tanımlayıcı normların bireylerin sosyal ikilem durumlarındaki iş birliği davranışını etkileyebileceği öngörülmektedir. Bu teorilere göre çalışmanın temel beklentisi, önleme odağ ${ }_{1}$ (prevention focus) durumsal olarak hazırlandığında ya da tanımlayıcı norm insanların çoğunun aynı durumda bencil davranışta bulunması şeklinde kurgulandığında toplum yanlısı bireylerin iş birliği davranışının azalacağıdır. Çalışma, düzenleyici odak ve normatif davranışın odağ1 teorileri ile sosyal değer yönelimleri yazınını bütünleştirerek bireylerin sosyal ikilem durumlarındaki tercihlerini anlamaya çalışması bakımından alan yazına özgün katkıda bulunmaktadır. Ayrıca, bu çalışma Türkiye'de sosyal ikilem durumlarında düşük iş birliği davranışı gösterilmesini en azından kısmen açıklayabilecek teorik bir model sınayarak pratik katkı da sağlamaktadır.

\section{Sosyal Değer Yönelimi}

Yaklaşık 45 yıldır devam eden araştırmalar bireylerin, sosyal değer yöneliminin (SDY; Messick ve McClintock, 1968) sosyal ikilemlerde birey davranışını önemli ölçüde etkilediğini göstermektedir (Bkz. Au ve Kwong, 2004; Balliet ve ark., 2009; Bogaert ve ark. 2008). Bir kişilik özelliği olarak kavramlaştırılan sosyal değer yönelimi, bireylerin kişisel fayda değerlendirmesi yaparken kendi çıktılarına ve diğer bireylerin çıktılarına atfettikleri değeri (pozitif veya negatif değer) ifade eder. Avrupa ve Kuzey Amerika ağırlıklı yürütülen araştırmalar bu toplumlardaki bireylerin çok büyük bir çoğunluğunun üç farklı sosyal değer yöneliminden birine sahip olduğunu ortaya koymuştur (Au ve Kwong, 2004; Bogaert ve ark., 2008; Karagonlar ve Kuhlman, 2013). Birinci grup hem kendi çıktılarına hem de diğer bireylerin çıktılarına pozitif değer veren; dolayısıyla kendilerinin ve diğerlerinin kazanımları toplamını, yani topluluğun refahını maksimize etme amacinda olan toplum yanlisı (prosocial) bireylerdir. Van Lange (1999) toplum yanlısı bireylerin aynı zamanda kendi çıktıları ve diğerlerinin çıktıları arasındaki eşitliğe de pozitif değer verdiklerini, dolayısıyla kazanımların eşitliğini maksimize etmeyi de amaçladıklarını göstermiştir. İkinci grup, kendi çıktılarına pozitif değer veren, diğer bireylerin çıktılarına pozitif ya da negatif herhangi bir değer vermeyen; dolayısıyla sadece kendi çıktılarını maksimize etmeyi amaçlayan bireycilerdir (individualist). Üçüncü grup ise kendi çıktılarına pozitif değer veren, fakat diğerlerinin çıktılarına negatif değer veren; dolayısıyla kendi kazanımları ile diğerlerinin kazanımları arasındaki farkı maksimi- 
ze etmeyi amaçlayan rekabetçilerdir (competitor). Rekabetçilerin batı toplumunda toplam nüfus içerisinde çok az bir oranı olması ve çeşitli sosyal ikilem yapılarında (mahkum ikilemi ve tavuk ikilemi vb.) bireycilerle benzer olarak bireysel çıkarlarını gözeten davranışlar göstermeleri nedeniyle bu iki grup alan yazında kendine yanlı (proself) kategorisi altında birleştirilmektedir (Au ve Kwong, 2004; Bogaert ve ark., 2008; Karagonlar ve Kuhlman, 2013). Sosyal değer yöneliminin sabit bir kişilik özelliği olduğuna dair güçlü kanıtlar vardır. Farklı çalışmalarda, birkaç haftadan altı aya kadar yapılan tekrarlı ölçümlerde test - tekrar test güvenilirliğinin orta ve yüksek düzeylerde olduğu gösterilmiştir (Kuhlman, Camac ve Cunha, 1986; Van Lange, 1999). Dahas1, sosyal değer yöneliminin bireylerin genetik özellikleri (Israel ve ark., 2009) ve çocukluk yaşamı deneyimleri (Van Lange, De Bruin, Otten ve Joireman, 1997) ile ilişkili olduğu gözlenmiştir.

Çeşitli sosyal ikilem paradigmalarında (mahkum ikilemi, kamu malları, kaynak ikilemleri) toplum yanlısı bireylerin kendine yanlılara kıyasla topluluk refahını düşünerek daha fazla iş birliği davranışı gösterdikleri görülmüştür (bir meta-analiz çalışması için bkz. Balliet ve ark., 2009). Sosyal değer yönelimlerinin iş birliği davranışı ile olan ilişkisinin dışsal geçerliliğini destekleyen bulgular da mevcuttur. Toplum yanlısı bireyler kendine yanlılara göre toplumsal kampanyalara daha fazla yardımda bulunma (Van Lange, Bekkers, Schuyt ve Van Vugt, 2007), daha yüksek çevre duyarlılı̆̆ gösterme (Van Vugt, Meertens ve Van Lange, 1995) ve vergi ödeme yükümlülüklerini daha fazla yerine getirme eğilimine sahiptirler (Brizi, Giacomantonio, Schumpe ve Mannetti, 2015). Kendine yanlılara kıyasla toplum yanlısı bireylerin adalet ve karşılıklılık normunu daha fazla benimsedikleri (Van Lange, 1999) ve daha yüksek sosyal sorumluluk bilincine sahip oldukları görülmüştür (De Cremer ve Van Lange, 2001). Diğer taraftan, araştırmalar toplum yanlısı bireylerin iş birliği davranışı göstermesinin karşı tarafın da iş birliği davranışı göstermesi şartına bağlı olduğunu, aksi durumda sömürülmemek için bireysel çıkarlarını kollayacaklarını ortaya koymaktadır (De Cremer ve Van Lange, 2001; Kelley ve Stahelski, 1970; Kuhlman ve Marshello, 1975; McClintock ve Liebrand, 1988; Pruit ve Kimmel, 1977; Van Lange, 1999; Van Lange ve Kuhlman, 1994). Örneğin, Kuhlman ve Marshello (1975) bireylerin anonim olarak eşleştikleri aynı partnerle birçok kez mahkum ikilemi oyununu oynadıkları bir deney çalışmasında, toplum yanlısı bireylerin ilk oyuna hep iş birliği yaparak başladıklarını ve daha sonraki oyunlarda kararlarını (iş birliği davranışı veya bencil davranış) partnerlerinin bir önceki oyun- 
daki hareketlerine göre verdiklerini göstermiştir. Buna göre, her oyunda iş birliği davranış1 gösteren bir partnere karşı toplum yanlısı bireyler \%100 iş birliği davranış1 göstermiş, ancak bencil davranış gösteren partnerlere karşı iş birliği yapmaktan kaçınmışlardır. Hedef-Beklenti teorisi ile uyumlu olarak Boone, Decklerk ve Kiyonari (2010) sosyal ikilemlerde toplum yanlısı bireylerin iş birliği davranışının genel güven düzeylerine ve diğer kişilerin davranışlarını öngörmek için kullanabilecekleri durumsal faktörlere/sosyal işaretlere (social cues) bağlı olabileceğini göstermiştir. Örneğin, yazarlar bir mahkum ikilemi oyununda eşleşmesi muhtemel kişilerin kısa süreli birbiriyle tanıştığ koşul (minimal temas koşulu) ile anonim kaldıkları koşulu karşılaştırdıkları bir deney çalışmasında, minimal temasın toplum yanlısı kişilerin iş birliği davranışını arttırdığını, kendine yanlıların iş birliği davranışını ise etkilemediğini göstermiştir. Yazarlara göre genel güven düzeyi ve minimal temas toplum yanlısı kişilerin sömürülme korkusunu azaltan etmenlerdir. Böyle etmenler kendine yanlıların iş birliği davranışını daha az etkilemektedir. Bu durum aşağıda bir örnekle ifade edilmektedir. Şekil 1'de simetrik bir mahkum ikilemi yapısındaki iki kişilik bir sosyal ikilemde X ve Y'nin ödeme matrisi gösterilmektedir. Bu matriste Ö ikili iş birliği davranışının Ödülünü, A tek taraflı bireysel çıkarı kollamanın Ayartıcıll̆ğıı, S tek taraflı iş birliği davranışı sonucu Sömürülmeyi ve C iki taraflı bireysel çıkarı kollamanın Cezasını temsil etmektedir. Buna göre, her iki birey için de diğerinin hareketi ne olursa olsun bireysel çıkarına göre davranmak en yüksek faydayı getirecektir. Oyun teorisi terminolojisine göre bireysel çıkarı kollama baskın stratejidir. Bu durumda amacı kişisel çıkarını kollamak olan kendine yanlı bir birey karşı taraf ne yaparsa yapsın iş birliği yapmayarak faydasını maksimize edeceğinden, karşı tarafın iş birliği yapacağına dair beklentinin (yani güvenin) ve sömürülme korkusunun kendine yanlı birey için herhangi bir önemi olmayacaktır. Diğer taraftan, iş birliği yapma hedefi olan toplum yanlısı birey, bu hedefi ancak ve ancak karşı tarafın da iş birliği yapacağına dair güveni olduğu takdirde gerçekleştirecektir. Aksi halde, birey sömürüye uğrayacaktır $(\mathrm{S}=1)$. Her iki birey de sömürülme korkusu veya bireysel çıkarın cazibesiyle kendi çıkarlarını kollarlarsa, beraberce topluluk çıkarını kolladıkları duruma $(\ddot{O}=5)$ göre daha az fayda sağlayacaklardır $(\mathrm{C}=2)$. 


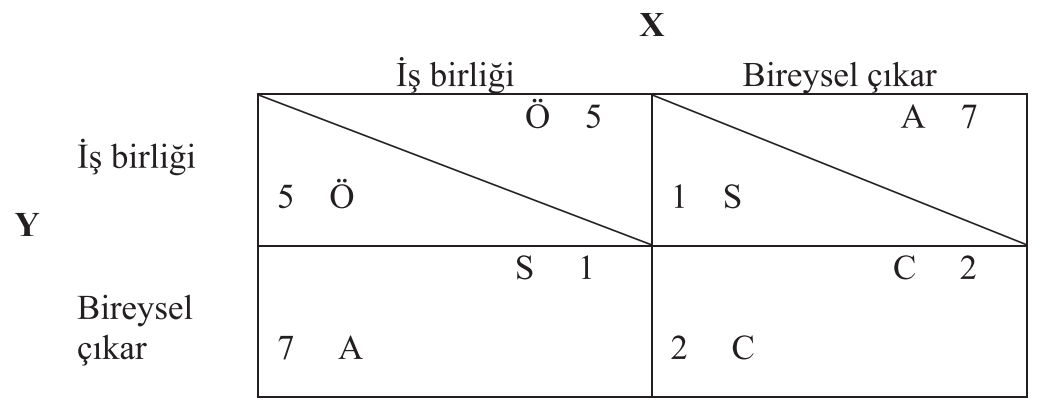

Şekil 1. İki Kişilik Mahkum İkilemi Örneği

Yukarıdaki tartışmaya göre sosyal ikilemlerde toplum yanlısı bireylerin iş birliği davranışları sömürülme korkuları ile ters orantılıdır. Toplum yanlısı bireylerin sömürülme korkusunu ve bu nedenle iş birliği davranışlarını etkileyecek önemli bir faktör durumsal düzenleyici odak (regulatory focus) olabilir.

\section{Düzenleyici Odak}

Düzenleyici odak teorisi (Higgins, 1997, 2012) hedonik prensibe göre bireyin zevk aldığı durumlara ulaşmak ve acı veren durumlardan kaçınmak amacıyla kullandığı birbirinden bağımsız iki farklı öz-düzenleyici yönelimin varlığını öne sürmektedir. Bunlar yükselme odağı ve önleme odağıdır. Düzenleyici odak bireyin farklı ihtiyaçlarını harekete geçirir ve bu ihtiyaçlara göre bireyin hedefleri kurgulama biçimini etkiler. Yükselme odağı ilerleme ve gelişme ihtiyaçlarını harekete geçirirken bu odağa sahip bir birey hedeflerini ulaşılması gereken idealler ve arzular olarak kurgular; önleme odağına sahip birey için ise güvenlik ve emniyet ihtiyacı ön plandadır ve birey hedeflerini yerine getirilmesi gereken yükümlülükler olarak görür (Higgins ve Spiegel, 2004). Dolayısıyla aynı hedef farklı düzenleyici odağa sahip bireyler tarafından farklı şekillerde kurgulanacaktır. Araştırmalar, düzenleyici odak türüne göre, hedefe ulaşma ve ulaşamamanın bireyler tarafından farklı şekillerde kurgulandığını ortaya koymaktadır. Buna göre yükselme odaklı bir kişi herhangi bir hedefe ulaşmayı (başarıyı) olumlu bir sonucun varlığı (kazanım) olarak görürken, hedefe ulaşamamayı (başarısızlığı) olumlu bir sonucun yokluğu (kazanım yok) olarak görmektedir. Önleme odağına sahip bir kişi ise herhangi bir hedefe ulaşmayı (başarıyı) olumsuz bir sonucun yokluğu (kayıp yok), hedefe ulaşamamayı (başarısızlığı) da olumsuz bir sonucun varlığı (kayıp) olarak görmektedir (Higgins ve Spiegel, 2004). 
Düzenleyici odak, hedefe ulaşmak için kullanılan araç ve stratejileri de etkiler (Crowe ve Higgins, 1997; Higgins, 2012). Buna göre, yükselme odaklı bireyler hedefe (olumlu sonuca) ulaşmak için arzu ve gayret gerektiren stratejiler kullanırlar. Örneğin, yükselme odaklı bir öğrenci sınavdan yüksek not almak için ekstra materyaller çalışabilir veya arkadaşlarıyla çalışma grubu oluşturabilir. Diğer taraftan önleme odaklı bireyler hedefe ulaşmak (olumsuz bir sonucun olmasını önlemek) için ihtiyatlı stratejiler izlerler ve sürekli tedbirli ve dikkatli olurlar. Dolayısıyla, aynı öğrenci önleme odağı aktif ise sınavla ilgili çalışmadığı materyal kalmadığından emin olacak ve sınavdan düşük not almasına sebep olabilecek durumları ortadan kaldıracaktır (örn., gece uykusunu etkileyebileceği için kahve içmeyecektir).

Araştırmalar ebeveynlerin de etkisiyle çocukluktan itibaren öz düzenleme yaparken kullanmaya alışılan baskın, kronik bir düzenleyici odağın bireyde varlığına işaret ederken (Higgins ve ark., 2001; Higgins, 1997), aynı zamanda bireyin davranışını yönlendiren aktif düzenleyici odağın durumdan duruma ve durumun özelliklerine göre kolaylıkla değişebileceğini ifade etmektedir (Bkz. Higgins, 2012; Higgins ve Spiegel, 2004). Dahası, alan yazındaki araştırmaların büyük bir kısmı düzenleyici odağın bu duruma bağlı özelliğine odaklanıp, düzenleyici odağı durumsal olarak manipüle etmektedir.

\section{Sosyal Değer Yönelimi, Düzenleyici Odak ve İş Birliği}

Daha önce de bahsedildiği üzere, düzenleyici odak hedefe ulaşmanın ve ulaşamamanın kurgulanış şeklini etkiler. Buna göre, Şekil 2a'da görüldüğü gibi sosyal ikilem durumunda topluluk çıkarını maksimize etmek isteyen, yani toplum yanlısı hedefi olan ve yükselme odağına sahip Y kişisi bu hedefine ulaşmayı bir kazanç (olumlu bir sonucun varlığı) olarak görecek, bu hedefe ulaşamamayı (sömürülme durumu) ise kazanç yok (olumlu bir sonucun olmaması) şeklinde görecektir. Diğer taraftan, Şekil 2b'de görüldüğü üzere, toplum yanlısı olan önleme odaklı Y kişisi toplum yanlısı hedefini gerçekleştirmeyi kayıp olmaması (olumsuz bir sonucun yokluğu), bu hedefi gerçekleştirememeyi ise kayıp olması (olumsuz bir sonucun varlığı) şeklinde kurgulayacaktır. Tversky ve Kahneman'1n $(1981 ;$ 1986) beklenti teorisinden hareketle, Idson, Liberman ve Higgins (2000) yükselme odaklı bireyin hedefe ulaşmasının (kazanç) önleme odaklı bireyin hedefe ulaşmasından (kayıp yok) daha fazla hoşnutluk yaratacağını (kazanç>kayıp yok); buna karşılık önleme odaklı bir bireyin hedefe ulaşamamasının (kayıp), yükselme odakl1 bireyin hedefe ulaşamamasından (kazanç yok) daha büyük bir 1zdırap getireceğini (kayıp > kazanç yok) göstermiştir. Bu durumu Şekil 2a ve 2b'ye uygularsak, ikili iş bir- 
liği davranışı toplum yanlısı olan yükselme odaklı bir bireye, toplum yanlısı olan önleme odaklı bir bireye nazaran daha büyük haz getirecektir (kazanç > kayıp yok). Tam tersine, tek taraflı iş birliği davranışı (sömürülme durumu) toplum yanlısı olan önleme odağındaki bir bireye, toplum yanlısı olan yükselme odağındaki bir bireye nazaran daha büyük ızdırap verecektir (kayıp > kazanç yok). Dolayısıyla toplum yanlısı bireyler arasında, yükselme odaklı olanlar önleme odaklı olanlara nazaran öncelikle topluluk refahını arttırma motivasyonuna sahip olacakken, önleme odaklı olanlar yükselme odaklı olanlara kıyasla öncelikle sömürülmeyi önleme motivasyonuna sahip olacaklardır. Tanımadıkları bireyler ile anonim etkileşime girecekleri bir durumda temkinlilikleri ve emniyet ihtiyaçları doğrultusunda hareket eden toplum yanlısı olan önleme odağı aktif bireyler sömürülmemek adına iş birliği davranışı göstermekten kaçınabilir.

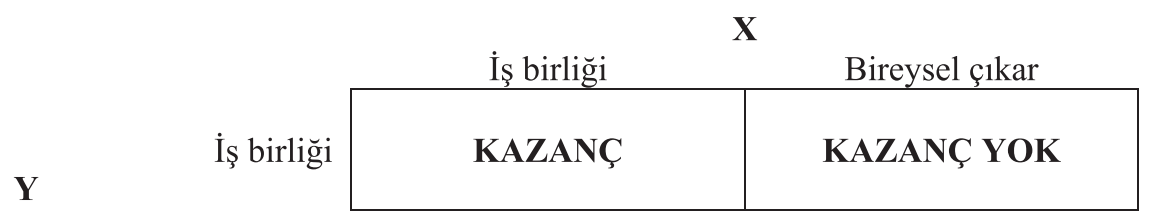

Şekil 2a. Yükselme Odağına Sahip Y'nin İş Birliğinin Sonuçları Not. Bu çalışmada düzenleyici odağın iş birliği davranışına etkisi incelendiği için mahkum ikilemindeki bireysel çıkar seçeneği kapsam dıșında olup burada irdelenmemiștir

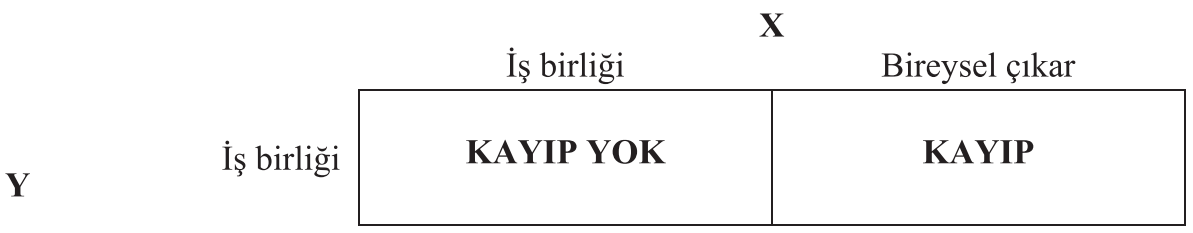

Şekil 2b. Önleme Odağına Sahip Y'nin İş Birliğinin Sonuçları Not. Bu çalışmada düzenleyici odağın iş birliği davranıșına etkisi incelendiği için mahkum ikilemindeki bireysel çıkar seçeneği kapsam dışında olup burada irdelenmemiştir.

Buna karşılık, toplum yanlısı olan yükselme odağı aktif bir bireyin sosyal ikilemlerde daha fazla iş birliği davranışı göstereceğine dair kanıtlar da mevcuttur. Yükselme odaklı bireyler daha hızlı karar verirken önleme odaklı bireyler (emniyet ihtiyaçları nedeniyle) daha sistematik ve analitik bir şekilde çevrelerini gözlerler (Förster, Higgins ve Bianco, 2003). Dolayısıyla, yükselme odaklı bireyler önleme odaklılara kıyasla çeşitli algısal kestirme yollara (heuristics) daha fazla başvurmakta ve yanılgılara (bias) daha fazla düşmektedir (Friedman ve Förster, 2001; Pham ve Avnet, 2009). Buna göre toplum yanlısı olan yükselme odağına sahip bir birey benzerlik varsayımı yanılgısına (as- 
sumed similarity bias; Kuhlman ve Wimberley, 1976) daha fazla düşebilir ve aksine çok açık bir kanıt yoksa (örn., karşı tarafın geçmiş davranışları), sosyal ikilemdeki diğer birey(ler)in de topluluk çıkarını maksimize etmeyi hedeflediğini varsayabilir. $\mathrm{Bu}$ da iş birliğine olumlu yansıyacaktır. Dahası, araştırmalar yükselme odaklı bireylerin riske karşı daha pozitif bir tutum sergilediğini, buna karşılık önleme odaklı bireylerin riskten kaçındığını göstermektedir (Gino ve Margolis, 2011). Toplum yanlısı olan yükselme odaklı bireylerin riske karşı genel olumlu tutumu sosyal ikilemlerde diğer bireylerin kendilerini sömürmeyeceği inancı (güven) olarak kendini gösterebilir. Diğer taraftan, toplum yanlısı olan önleme odaklı bireylerin riske karşı negatif tutumu, tanımadıkları bireylerle anonim ilişkilerde düşük iş birliği davranışı göstermelerine yol açabilir.

Diğer taraftan, hedef-beklenti teorisine göre (Pruitt ve Kimell, 1977) bireyin iş birliği davranışı göstermesinin ön koşulunun böyle bir hedefi/güdüsü olması olduğu hatırlanırsa kendine yanlı bireylerin sosyal ikilemlerde iş birliği davranışı göstermesinin aktif düzenleyici odağa göre daha az farklılaşması beklenebilir. Bu tartışmalar ışığında aşağıdaki hipoteze ulaşılmıştır:

H1. a) Toplum yanlısı bireyler, yükselme odağına kıyasla, önleme odağı hazırland1ğında daha düşük iş birliği davranışı gösterecektir ve $b$ ) kendine yanlı bireylerin iş birliği davranışı gösterme düzeyi ise aktif düzenleyici odağa göre daha az farklılık gösterecektir.

\section{Tanımlayıcı Normların Rolü}

Van Lange ve Kuhlman (1994) toplum yanlısı bireylerin davranışlarının sosyal ikilemlerde etkileşime girdikleri kişilerle ilgili izlenimlerine göre değiş̧ebildiğini göstermiştir. $\mathrm{Bu}$ yazarların çalışmasına göre toplum yanlısı kişiler etkileşime girdikleri bireyleri ahlaki açıdan değerlendirmekte ve dürüst olarak gördükleri kişilerle daha çok iş birliği yapmaktadır. Kendine yanlıların ise etkileşime girdikleri bireyleri güç ve zeka açısından değerlendirdikleri ancak, kendine yanlıların sosyal işaretlere daha az dikkat etmeleri sebebiyle iş birliği davranışı gösterme düzeylerinin bu değerlendirmeden anlamlı düzeyde etkilenmediği görülmüştür. Sosyal ikilem durumlarında bireyler diğer kişiler ile ilgili izlenim oluşturmak için kişisel bilgiye her zaman ulaşamayabilirler. Günümüzde bireyler arası sosyal etkileşimlerin de her geçen gün kısa süreli ve anonim hale gelmesi bunu güçleştiren bir etmendir (Nowak ve Sigmund, 2005). Sosyal ikilem durumlarında toplum yanlısı bireylerin diğer kişilerin nasıl davranacağını öngörmesine 
olanak veren, dolayısıyla sömürülme korkularının düzeyini belirleyen ve bireylerin anonim etkileşimlerde de nispeten kolay gözlemleyebileceği etmenlerden biri ortamdaki tanımlayıcı normlar (descriptive norms) olabilir.

Cialdini ve arkadaşları (Cialdini ve ark., 1990; Kallgren, Reno ve Cialdini, 2000) tarafından geliştirilen normatif davranışın odağı (Focus theory of normative conduct) teorisine göre herhangi bir durumda davranışı yönlendiren iki farklı ve bağımsız norm vardır: 1) doğru davranışı belirten buyruksal (injunctive) normlar, 2) bireyler tarafından gerçekte gösterilen davranışı belirten tanımlayıcı (descriptive) normlar. Buyruksal normlar topluluğun ahlaki prensiplerini gösterir ve olması gereken davranışı sosyal ödüller ve cezalar vasıtasıyla güdüler (Cialdini, Kallgren ve Reno, 1991). Tanımlayıcı normlar ise bir durumda fayda sağlayacak davranış ile ilgili bireye yol gösterir (örn., Eğer bu durumda çoğu kişi böyle davranıyor/düşünüyor ise, bu davranışta bulunmak mantıklıdır; Cialdini ve ark., 1991). Diğer bir ifadeyle tanımlayıcı normlar bilgiye daya1 sosyal etkide bulunur ve bireyin kısa sürede etkili karar almasını sağlar. Bu iki norm birbiriyle aynı yönde olabileceği gibi çelişebilir. Buyruksal normlar ile tanımlayıcı normların birbiriyle çeliştiği durumda hangisi belirgin (salient) ise davranışı o norm yönlendirecektir. Çalışmalar, buyruksal normların yeterince belirgin olmadığı durumlarda birey davranışlarının tanımlayıcı normlardan etkilendiğini göstermektedir. Örneğin, her tarafı çöp dolu bir parkta, çevreyi kirletmeme buyruksal normu bireylere belirgin yapılmazsa bireyler diğer insanların attıkları çöpleri dikkate alarak (tanımlayıcı norm) parka çöp atmakta bir sakınca görmeyeceklerdir (Bkz. Cialdini ve ark., 1990). Arizona ulusal orman parkında yapılan bir deneyde (Cialdini, 2003) ziyaretçilere tanımlayıcı normları veya buyruksal normları belirgin yapan uyarı levhaları konulmuştur. Tanımlayıcı normu belirgin yapan Geçmişteki birçok ziyaretçi parkın doğal yapısını bozsa da bu parktan odun alıp götürmüştür mesajı ile buyruksal normu belirgin yapan Lütfen, parkın doğal yapısını korumak için buradan odun almayın mesajının etkinliği karşılaştırıldığında tanımlayıcı normu içeren mesajın odun hırsızlığını anlamlı biçimde arttırdığı gözlenmiştir. Bir başka deneyde ise (Cialdini, 2003) birçok kişinin geri dönüşüm yapt1ğına dair bir tanımlayıcı norm belirgin kılındığında bireylerin geri dönüşüm yapma eğiliminde artış görülmüştür.

Toplum yanlısı bireylerin iş birliği davranışının çevredeki sosyal işaretlerden daha çok etkilendiği göz önüne alınırsa, belirli bir sosyal ikilem durumunda insanların genelde nasıl davrandığına dair bir tanımlayıcı norm manipülasyonunun (iş birliği normu 
veya kişisel çıkarı kollama normu) kendine yanlılara kıyasla toplum yanlısı bireylerin iş birliği davranışı gösterme düzeyini daha fazla etkileyeceği öne sürülebilir. Bu doğrultuda aşağıdaki hipoteze ulaşılmıştır:

H2. a) Toplum yanlısı bireyler tanımlayıcı norm iş birliği olduğunda, tanımlayıcı normun kişisel çıkarı kollama olduğu duruma kıyasla daha yüksek iş birliği davranışı gösterecektir ve b) kendine yanlı bireylerin iş birliği davranışı tanımlayıcı normdan daha az etkilenecektir.

Diğer taraftan, mevcut alan yazın, düzenleyici odağın tanımlayıcı normlara duyarlılık üzerinde de bir etkisi olacağına işaret etmektedir. Araştırmalar, bireyin istek ve arzularına yoğunlaşmasının (yükselme odağı) içsel süreçlere odaklanmasını; dikkat ve tedbirlilik ihtiyacı üzerine yoğunlaşmasının (önleme odağı) ise tehditlere karşı hazırlıklı olabilmesi için çevreden sağlanan bilgiye (tanımlayıcı norm gibi) daha fazla odaklanmasını sağladığını göstermektedir (Bless ve ark., 1996; Pham ve Avnet, 2009). Bu doğrultuda toplum yanlısı bireyler önleme odağı aktif olduğunda tanımlayıcı norma daha duyarlı olabilirler. Eğer bir sosyal ikilem durumunda çoğunluk kişisel çıkarını kolluyor ise (tanımlayıcı norm kişisel çıkarı kollamak ise), toplum yanlısı olan önleme odaklı bireylerin sömürülme korkuları yüksek olacak (diğer kişi ya da kişilerin iş birliği yapacağına dair beklentileri düşük olacak) ve bireyler sömürülmemek için tanımlayıcı norma göre hareket ederek bencil davranacaklardır. Buna karşılık, tanımlayıcı norm çevredeki bireylerin iş birliği gösterdiğini işaret ediyorsa, toplum yanlısı olan önleme odaklı bireyin sömürülme korkusu azalacak ve birey daha fazla iş birliği davranışı gösterecektir. Buna göre aşağıdaki hipoteze ulaşılabilir:

H3. Sosyal değer yönelimi $x$ düzenleyici odak $x$ tanımlayıcı norm üçlü etkileşimi iş birliği davranışını etkileyecektir ve toplum yanlısı bireyler arasında, önleme odaklı bireylerin yükselme odaklı bireylere kıyasla iş birliği davranışı tanımlayıcı normlardan daha fazla etkilenecektir.

\section{Cinsiyetin Rolü}

Cinsiyet rollerinin hem evrimsel hem de toplumsal gelişiminden yola çıkarak, kad1na ve erkeğe yüklenen farklı rollerin bireylerin iş birliği davranışı da dahil olmak üzere kişiler arası etkileşimleri farklı şekillerde etkileyeceği ileri sürülebilir. Örneğin, insan toplumunun kültürel evriminin bir parçası olarak toplumun erkeğe savunmacı - savaşçı bir rol (male-warrior) yüklediği ifade edilmektedir. Bu yazına göre erkekler kadınlara 
kıyasla dışarıdan gelen tehditlere daha fazla tepki verirler ve bu sebeple kadınların ve erkeklerin sosyal ikilem durumlarında diğer kişiler tarafından sömürüye uğrama konusunda risk algıları ve dolayısıyla iş birliği davranışları farklılık gösterebilir (Vugt, Cremer ve Janssen, 2007). Benzer şekilde, kadın ve erkeğin toplumsal cinsiyet rollerinin farklılığı argümanı 1şı̆̆ında, Seguino, Stevens ve Lutz (1996), sosyal ikilem durumunda kadınların erkeklerden daha fazla iş birliği davranışı gösterdiğini ortaya koymuştur. Yazarlar, cinsiyetin bu etkisini kadınların ataerkil toplum içinde çocuk yetiştirmek ve grup içindeki kişilerin bakımını üstlenmek gibi görevleri sebebiyle erkeklere kıyasla daha fazla özgeci ve daha az bencil olacağı savıyla açıklamaktadır. Diğer taraftan, bazı çalışmalarda iş birliği davranışının cinsiyete göre değişmediği bulunmuş (Caldwell, 1976; Sell, 1997) ve bu sebeple cinsiyetin iş birliği davranışı gösterme açısından rolünün fazlaca abartıldığı ifade edilmiştir (Stockard, van de Kragt ve Dodge, 1988). Mevcut alan yazın dikkate alındığında, bu çalışmada cinsiyetin iş birliği davranışı üzerindeki rolünü formel hipotezler yoluyla incelemeyi gerekçelendirecek yeterli kanıt olmasa da, keşifsel bazı analizler gerçekleştirmenin faydalı olacağı düşünülmüştür. Bu bağlamda, cinsiyetin iş birliği davranışı üzerindeki ana etkisinin yanı sıra, düzenleyici odak ve tanımlayıcı normların toplum yanlısı bireylerin iş birliği davranışı üzerindeki etkisinin cinsiyete göre farklılık gösterip göstermediği incelenecektir. Yukarıdaki cinsiyete dair yaklaşımlar 1şı̆̆ında, önleme odağının ve bencil davranışı işaret eden tanımlayıcı normların, (özellikle toplum yanlısı) erkeklerin iş birliği davranışını kadınlara kıyasla daha olumsuz etkileyeceği beklenebilir.

\section{YÖNTEM}

\section{Katılımcılar}

Ön Test. Türkiye'de bir üniversitenin farklı birimlerinde okuyan yaklaşık 13.000 öğrenciye e-posta ile bir ön test linki yollanmış, yapılacak çalışma kısaca tanıtılmıştır. Ön testte 12 maddelik sosyal değer yönelimleri ölçeği verilmiştir. Ayrıca, bireylerden çeşitli demografik bilgiler (örn., sosyoekonomik statü, fakülte ve iletişim bilgileri) istenmiştir.

Ön teste 1.192 kişi katılmıştır. Yazınla uyumlu olarak, bu kişiler arasında sosyal değer yönelimi tutarlılık skoru 60’ın altında olanlar ve toplum yanlısı, bireyci ve rekabetçi değer yönelimi dışında bir yönelime sahip olanlar veri seti dışında tutulmuştur. Tutarlı bir sosyal değer yönelimi olan toplam 930 kişinin \%33’ü toplum yanlısı, \%28’i bireyci, 
\%34'ü rekabetçi, \%5'i ise diğer değer yönelimlerine sahiptir. Batı örneklemleriyle k1yaslandığında toplum yanlısı kişi yüzdesi az, rekabetçi kişi yüzdesi ise oldukça yüksek görünmektedir (Au ve Kwong, 2004; referans değerler: toplum yanlısı yaklaşık \%45, bireyci yaklaşı1k \%30, rekabetçi yaklaşık \%15).

Deney Çalışması Örneklemi ve Deney Deseni. Ön teste katılan ve sosyal değer yönelimleri toplum yanlısı, bireyci veya rekabetçi olan kişiler arasından iletişim bilgilerini sağlayanlar ile iletişime geçilmiş ve bu kişiler çalışmaya davet edilmiştir. Çalışmaya toplamda 290 kişi katılmıştır. Verisi eksik olan bir kişi veri setinden çıkartılmış ve analizler, geriye kalan 289 kişi üzerinden yürütülmüştür. Verisi kullanılan 289 kişinin 133'ü (\%46) kadın, 156’sı (\%54) erkektir. Katılımcıların 10 üzerinden değerlendirdikleri öznel sosyoekonomik düzeyleri ortalamanın üzerindedir (Ort. $=6.19, S S=1.66)$. Katılımcıların \%35.7'si (103 kişi) mühendislik, mimarlık ve fen bilimleri, geriye kalanı ise sosyal bilimler ve eğitim bilimleri (\%64.3) öğrencisidir. Ayrıca deneye katılan kişilerin $111^{\prime} \mathrm{i}(\% 38.4)$ toplum yanlıs1, 83'ü (\%28.7) bireyci, geriye kalan 95'i (\%32.9) ise rekabetçidir. Diğer bir ifadeyle, katılımcıların \%61.6’sı (178 kişi) kendine yanlı bireylerden oluşmaktadır. Deneyde mahkumun ikilemi paradigması kullanılmış ve düzenleyici odak (önleme veya yükselme koşulu) ve tanımlayıcı norm (bencil davranış normu, iş birliği normu veya kontrol koşulu) değişkenleri katılımcılar-arası bir desen ile manipüle edilmiştir.

\section{Veri Toplama Araçları}

Sosyal Değer Yönelimleri Ölçümü. Sosyal değer yönelimleri, Liebrand (1984) tarafından geliştirilen Çember Ölçeği ile deneyden yaklaşık üç hafta önce ölçülmüştür. Bu ölçek uygulamasında bireyler kendileri ile tanımadıkları ve hiç tanımayacakları hayali bir diğer kişi arasında olan çeşitli puan dağılımlarına dair tercihlerini belirtmektedirler. Katılımcılara, 12 farklı durum için kendileri ve diğer kişi arasında nasıl bir dağılım tercih ettikleri sorulmuştur (Bkz. Karagonlar ve Kuhlman, 2013). Her bir durumda, bireyin kendisi ve diğer kişi için farklı puan dağılımlarını ifade eden iki seçenek vardır (A ve B) ve bireyler her bir durumda bu iki seçenekten birini tercih ederler. Örnek bir durumda katılımcı, kendisinin 400 puan diğer kişinin 100 puan aldığı A seçeneği ile kendisinin 500 puan diğer kişinin 300 puan aldığı B seçeneği arasında bir tercih yapmaktadır. Katılımcılara, eşleştikleri diğer kişinin de aynı dağılımlar ile ilgili tercih yapacağı bilgisi verilmiştir. Ayrıca, katılımcıların alacakları toplam puanın hem kendi hem de diğer kişinin tercihlerine göre belirleneceği ve diğer kişinin alacağ 1 toplam puanın da hem diğer 
kişinin hem de katılımcının tercihlerine göre hesaplanacağı belirtilmiştir. Son olarak katılımcılara bu uygulamada ne kadar çok puan toplarlarsa o kadar iyi olduğu ifade edilmiştir.

Çember Ölçeğinde, her bir dağılım yarıçapı 100 birim olan bir çemberin üzerinde yer alan noktalardan seçilmektedir. Bireylerin 12 durumda yaptığı tercihlere göre toplamda kendi puanı (çemberin x ekseni üzerinde bir nokta) ve diğer kişinin puanı (çemberin y ekseni üzerinde bir nokta) belirlenir. X ekseni ve Y ekseninde elde edilen noktaların koordinatları bireyin sosyal değer yönelimi vektörünü verir. Bu vektörün $\mathrm{X}$ ekseni ile olan açısı bireyin sosyal değer yönelimi açı değeri, vektörün uzunluğunun yarıçapa oranı ise bireyin tutarlılık indeksini verir. Bir bireyin tutarlı olarak değerlendirilmesi için bu indeksin en az 60 olarak alınması uygulamadaki genel prensiptir (Au ve Kwong, 2004; Balliet ve ark., 2009; Bogaert ve ark., 2008). Bu çalışmada yazınla uyumlu olarak minimum tutarlılık indeksi değeri 60 olarak alınmıştır.

Çember Ölçeği ile hesaplanan açı değeri Tablo 1'deki gibi kategorilere ayrılabilir. Örneğin 22.5 derece ile 67.5 derece aralığı toplum yanlısı olarak ifade edilmektedir. Diğer taraftan, toplumda en sık rastlanan üç değer yönelimi (toplum yanlısı, bireyci ve rekabetçi) kişisel kazanımlara verilen olumlu değer bakımından aynı olmakta, sadece bireyin diğer kişilerin kazanımlarına verdiği değer bakımından farklılaşmaktadır. Dolayısıyla bu değer yönelimlerine odaklanan çalışmalarda SDY açısı (-67.5 derece ile 22.5 derece aralığında) sürekli değişken olarak ifade edilebilir (Au ve Kwong, 2004; Liebrand, 1984). Buna göre SDY açı değeri arttıkça bireyin toplum yanlılığı, diğer bir ifadeyle iş birliği davranışı gösterme yönelimi yükselmektedir. Alan yazında istatistiksel gücü arttırmak ve tip 2 hatasını azaltmak için sosyal değer yönelimini toplum yanlısı ve kendine yanlı olarak kategorileştirmek yerine sürekli bir değişken olarak işlemselleştiren geçmiş çalışmalar 1şı̆̆ında (Bkz. Bogaert, Boone ve van Witteloostuijn, 2012; Karagonlar ve Neves, 2020) bu çalışmada da SDY teorik olarak -67.5 ve 22.5 derece aralığında değişen (açı değeri arttıkça bireyin toplum yanlısı yönelimi artmakta) sürekli bir değişken olarak işlemselleştirilmiştir. 
Tablo 1. Sosyal Değer Yönelimleri Açı Dönüşüm Tablosu

\begin{tabular}{lcccc}
\hline & Sosyal Değer Yönelimi & \multicolumn{3}{c}{ Açı aralığı } \\
\hline 90 & Altrustik & 112.5 & ve & 67.5 \\
45 & Toplum yanlısı & 67.5 & ve & 22.5 \\
0 & Bireyci & 22.5 & ve & -22.5 \\
-45 & Rekabetçi & -22.5 & ve & -67.5 \\
-90 & Agresif & -67.5 & ve & -112.5 \\
225 & SadoMazoşist & 247.5 & ve & 202.5 \\
180 & Mazoşist & 202.5 & ve & 157.5 \\
135 & Şehitlik & 157.5 & ve & 112.5 \\
\hline
\end{tabular}

Düzenleyici Odak Manipülasyonu. Bireylerin düzenleyici odağı yazında daha önce sıkça kullanılan ve geçerliği test edilmiş olan labirent oyunu ile manipüle edilmiştir (Baas, De Dreu ve Nijstad, 2011; Friedman ve Förster, 2001; Gino ve Margolis, 2011; Wan, Hong ve Sternthal, 2009). Bu yöntem, katılımcılara belirgin olmayan bir şekilde ve mahkumun ikilemi oyunundan bağımsız olarak düzenleyici odağı hazırlayabilmektedir (priming). Buna göre bireylere ortasında bir farenin yer aldığı bir labirent verilmektedir. Yükselme odağı koşulunda labirentin sonunda bir peynir bulunmaktadır. Peynir gelişme gösterme ve peynire doğru ilerleme hedefini temsil etmekte ve semantik olarak bireyin doyum ihtiyacını harekete geçirmektedir. Önleme odağı koşulunda ise labirentin üzerinde uçan ve fareyi avlamaya çalıştığı izlenimi veren bir baykuş vardır. $\mathrm{Bu}$ baykuş, semantik olarak bireylerde güvenlik ve emniyet ihtiyacını harekete geçirmektedir. Buna göre, Qualtrics üzerinde bireyler rassal olarak ve yaklaşık olarak eşit olacak şekilde önleme odağ1 (baykuş) veya yükselme odağ1 (peynir) koşullarına atanmıştır. Buna göre katılımcıların yaklaşık yarısı (144 kişi) yükselme odağı koşuluna, diğer yarısı (145 kişi) ise önleme odağı koşuluna rassal olarak atanmışlardır. Labirenti gösteren ekranı takiben katılımcılardan kendilerini labirentteki farenin yerine koyduklarında ne hissedeceklerini yazmaları istenmiştir (Wan ve ark., 2009).

İş Birliği Davranışı. Bireylerin iş birliği davranışını ölçmek için bir sosyal ikilem oyunu olan mahkumun ikilemi oyunu oynatılmıştır. Mevcut yazın ile uyumlu olarak katılımcılara 10.000 kişilik bir katılımcı havuzundan rastgele eşleştikleri bir kişi ile bir karar verme oyunu oynayacakları söylenmiştir (Kiyonari, Yamagishi, Cook ve Cheshire, 2006; Yamagishi ve ark., 2013). Tüm katılımcılara 100 deney parası verilmiş (Fehr ve Gächter, 2002; Gächter ve Fehr, 1999) ve her katılımcının deney sonunda elde edeceği gerçek paranın eşleştikleri kişi ile karşılıklı verecekleri kararların sonucunda belirleneceği ifade edilmiştir. Katılımcıların ellerindeki paranın diledikleri miktarını (0 ile 100 
arasında) eşleştikleri kişiye yollayabilecekleri, aynı şekilde diğer kişinin de elindeki paranın dilediği miktarını eşleştiği katılımcıya gönderebileceği bilgisi verilmiş̧ir. Ayrıca, sosyal ikilem alan yazınını takiben katılımcıların yolladıkları paranın ve eşleştikleri kişiden kendilerine gelen paranın 1.5 katsayısı ile çarpılacağı söylenmiştir (burada amaç oyunu mahkumun ikilemine dönüştürebilmektir). Her oyunun sonunda katılımcının sahip olacağı paranın 100 deney parasından elinde tuttuğu para (karşı tarafa yollamadığ miktar) ile diğer katılımcının kendisine yolladığı paranın 1.5 katının toplamı olacağ birçok örnek senaryo ile katılımcılara açıklanmıştır.

Ayrıca her katılımcının havuzdan iki farklı katılımcıyla (Diğer Kişi 1 ve Diğer kişi 2) rastgele eşleştirildiği ve oyunu eşleştikleri her katılımcıyla sadece bir kez olmak üzere toplamda iki defa oynayacakları ve sadece bir eşleşmelerinden elde edecekleri parasal kazanımlarının kendilerine ödeneceği bilgisi verilmiştir. Hangi eşleşmede elde ettikleri kazanımlarının ödeneceğinin ise rastgele belirleneceği, dolayısıyla her iki eşleşmede verecekleri kararların birbirinden bağımsız değerlendirilmesi gerektiği örnek ile vurgulanmıştır (benzer uygulama için bkz. Chen ve Bachrach, 2003). Bu uygulama, katılımcıların stratejik olarak iki oyunu beraber düşünmesinin önüne geçmekte ve $H 1$ ile H3'ün birbirinden bağımsız test edilmesini sağlamaktadır. Aldatmacanın inandırıcılığını korumak ve stratejik karar almayı engellemek için, katılımcılara sözde eşleştikleri kişilerin kendilerine ne kadar para gönderdiğinin deney tamamlandıktan sonra belli olacağı ifade edilmiştir. Tüm deney oturumları tamamlandıktan sonra her katılımcıya net $25 \mathrm{TL}$ katılım ücreti ödenmiştir.

Tanımlayıcı Norm Manipülasyonu. Bireylerin ilk oyun sonundaki kazanımlarının ikinci oyundaki davranışlarını etkilememesi için ilk oyunlar sonunda bireylere kendilerine karşı taraftan gönderilen para miktarı ile ilgili herhangi bir geri bildirim verilmemiştir. Birinci oyun sonunda, katılımcılar ikinci oyuna başlamadan önce tanımlayıcı norm manipülasyonu yapılmıştır. İnandırıcılığı arttırmak için tanımlayıcı norm koşullarında küsuratlı sayılar verilmiştir. Yine aynı sebepten, 100'e veya 0'a çok yakın değerler seçilmemiştir. Buna göre, katılımcılar üç farklı tanımlayıcı norm koşulundan (iş birliği normu, bencil davranış normu, kontrol) bir tanesine rassal ve yaklaşık olarak eşit olacak şekilde atanmışlardır. Buna göre 97 kişi (\%33.6) yüksek iş birliği normu koşuluna, 98 kişi (\%33.9) bencil davranış normu koşuluna, geriye kalan 94 kişi (\%32.5) kontrol koşuluna atanmıştır. Tanımlayıcı normun iş birliği olduğu koşulda birinci oyun sona erdikten sonra kişinin ekranında şimdiye kadar oturumlara katılan tüm katılımcıların 
eşleştikleri kişilere ortalama 80.44 deney parası gönderdiği bilgisi görüntülenmiştir. Tanımlayıcı normun bencil davranış olduğu koşulda ise gönderilen paranın ortalama 15.10 deney parası olduğu bilgisi verilmiştir. Tanımlayıcı normun olmadığg kontrol koşulunda ise katılımcılara ortalama gönderilen para konusunda hiçbir bilgi verilmemiştir.

Tanımlayıcı Norm Manipülasyonu Kontrolü. Tanımlayıcı norm manipülasyonu (iş birliği normu veya bencil davranış normu) yazın bağlamında bu çalışma için özel olarak kurgulanmıştır. Bu sebeple buradaki norm manipülasyonunu kontrol etmeyi sağlayacak sorular, mevcut çalışmaya özgün manipülasyonu tam olarak değerlendirmesi için yazarlar tarafından geliştirilmiştir. Sorular, katılımcıların bulundukları koşulda diğer katılımcıların iş birliği davranışının düşük ya da yüksek olmasına dair algılarını ölçmektedir (Benzer uygulamalar için bkz. Köbis, Van Prooijen, Righetti ve Van Lange, 2015; Staunton, Louis, Smith, Terry ve McDonald, 2014). İkinci oyun sona erdikten sonra tanımlayıcı norm manipülasyonunun kontrolü şu dört soru ile yapılmıştır: "İnsanların diğer kişiye gönderdiği ortalama miktar yüksektir. Genelde insanlar ellerindeki paranın büyük bir kısmını diğer kişiye göndermektedirler. İnsanlar 100 deney parasının küçük bir kısmını ellerinde tutmakta; önemli bir miktarını ise diğer kişiye göndermektedir. Bu çalışmada eşleşeceğiniz herhangi bir kişinin size büyük bir miktar para göndermesi yüksek ihtimaldir." Katılımcılar 5'li bir Likert ölçeğini kullanarak (1 = Hiç katılmıyorum, 5 = Tamamılla katılıyorum) bu sorulara yanıt vermişlerdir. Ölçeğin Cronbach alfa iç tutarlılık katsayısı .81 olarak bulunmuştur.

Kontrol Değişkenleri. Araştırma modelinin analizinde muhtemel karıştırıcı etkilerin azaltılması için iki kontrol değişkeni ölçümlenmiştir. İlk olarak, mevcut yazını takiben farklı düzenleyici odak koşullarının katılımcılar üzerinde farklı duygu durumları yaratabileceği (Baas ve ark., 2011; Friedman ve Förster, 2001) ve farklı duygu durumlarının da iş birliği davranışını etkileyebileceği (Eisenberg, 1991) göz önüne alınarak katılımcıların duygu durumları analizlerde kontrol edilmiştir. Tanımlayıcı norm manipülasyon kontrolünden sonra duygu durumlarını ölçmek için katılımcılara Mayer ve Gaschke (1988) tarafından geliştirilen ve Fairbairn ve Sayette (2013) tarafindan uyarlanan Duygu durum ölçeği (Brief Mood Introspection Scale) verilmiştir. Ölçeğin farklı zaman aralıklarındaki Cronbach alfa güvenilirlik katsayısı olumlu duygu durum için .86 ile .96 arasında, olumsuz duygu durum için .84 ile .87 arasında rapor edilmiştir. Bu ölçek yazında birçok çalışma tarafından başarılı bir şekilde kullanılmış ve geçerliliği test edilmiştir (Maner, DeWall, Baumeister ve Schaller, 2007; Tice, Bratslavsky ve Bau- 
meister, 2001). Katılımcılar olumlu duyguları (neşeli, mutlu, memnun) ve olumsuz duyguları (gergin, endişeli, üzgün, moralsiz) o anda ne ölçüde hissettiklerini dörtlü bir ölçek üzerinde belirtmişlerdir $(1=$ Şu anki ruh halimi hiç yansıtmıyor, $4=$ Şu anki ruh halimi çok yansıttyor). Bu çalışmada Cronbach alfa güvenilirlik katsayısı olumlu duygu durum için .75 , olumsuz duygu durum için .65 olarak bulunmuştur.

İkinci olarak, bireylerin sosyoekonomik düzeyleri arttıkça toplum yanlısı davranışlarının azaldığını gösteren çalışmalar ışı̆̆ında (Martinsson, Villegas-Palacio ve Wollbrant, 2015; Piff, Kraus, Côté, Cheng ve Keltner, 2010) sosyoekonomik düzeyin ana etkileri kontrol edilmiştir. Sosyoekonomik düzey ön-test aşamasında ölçülmüştür. Bunun için Adler, Epel, Castellazzo ve Ickovics'in (2000) tek maddelik merdiven ölçeği kullanılmıştır. Bu ölçekte bireylere 10 basamaklı bir merdiven gösterilmekte, bu merdivenin basamaklarının insanların ekonomik ve sosyal statülerine göre toplumdaki yerini temsil ettiği ifade edilmekte ve bireylerin kendilerini hangi basamakta gördükleri sorulmaktadır.

Düzenleyici Odak Manipülasyon Kontrolü. Duygu durum ölçümünden sonra, düzenleyici odak manipülasyon kontrolü Gino ve Margolis'in (2011) çalışmalarında kullandığı soru ile yapılmıştır. Buna göre, katılımcılardan birinci çalışmada gördükleri resmin içeriğini tarif etmeleri istenmiştir (labirentin içinde bir fare ve peynir veya labirentin içinde bir fare ve onu yemeye çalışan bir yırtıcı kuş vb.).

\section{İşlem}

$\mathrm{Bu}$ çalışma bir ulusal proje kapsamında yürütülmüş olup yürütücünün bağl1 olduğu kurumdan etik kurul onay belgesi alınmıştır.

Deney yaklaşı 30 kişilik bir bilgisayar laboratuvarında 10-15 kişilik oturumlar halinde aynı görevli tarafından Qualtrics yazılımı aracılığı ile yürütülmüştür. Her oturum yaklaşı 30 dakika sürmüştür. Oturumlar, katılımcılar mümkün olduğunca farklı fakültelerden olacak şekilde düzenlenmiştir. Katılımcılar kendilerine belirtilen saatte deneyin yapılacağı laboratuvarın önünde araştırma görevlisi tarafından karşılanmış ve birbirlerinin monitörlerini göremeyecekleri bir oturum düzeninde bilgisayarlara yerleştirilmişlerdir. Tüm katılımcılara deneyden önce bir kod numarası atanmıştır ve bu kod numarası deney sırasında katılımcılara verilen dosyalara yazılmıştır. Kod numarasının amacı katılımcıların ön testte toplanan verileri ile (sosyal değer yönelimleri, demografik veriler) deney verilerini herhangi bir yere isimlerini yazmadan, anonim bir şekilde eşleştirebil- 
mektir. Katılımcılar laboratuvara yerleştirildikten sonra bilgilendirilmiş gönüllü onam formlarını imzalamış ve yönergeler başlamıştır. Deneyde oturumlar arasında standardizasyon sağlamak amacıyla tüm yönergeler bir Microsoft Power Point sunusu ve bu sunuya eklenen ses kaydı ile bir seferde sunulmuştur. Yönergeleri takiben düzenleyici odak manipülasyonu yapılmış, ardından katılımcılar mahkumun ikilemi oyununu oynamıştır. Mahkumun ikilemi oyunu her biri farklı kişilerle olmak üzere iki defa oynanmıştır. İkinci oyun öncesi tanımlayıcı norm manipülasyonu yapılmıştır.

Deney yönergelerinde düzenleyici odak manipülasyonu ve sosyal ikilem oyunu (mahkumun ikilemi oyunu) arasında ilişki kurulmasını önlemek amacıyla katılımcılara iki ayrı çalışmaya katılacakları bilgisi verilmiştir. İlk çalışmanın (düzenleyici odak manipülasyonu) amacı katılımcıların kendilerine ve olaylara bakış açılarını anlamak olarak, ikinci çalışmanın amacı ise bireylerin sosyal kararlarının incelenmesi şeklinde ifade edilmiştir. Bu genel açıklamadan sonra ilk çalışma olarak isimlendirilen ve düzenleyici odağı manipüle etmek için kullanılan labirent uygulaması ve ikinci çalışma olarak isimlendirilen mahkumun ikilemi oyunu ile ilgili detaylı yönergeler örnekler ile sunulmuştur (ikinci çalışma boyunca hiçbir zaman mahkumun ikilemi ismi kullanılmamıştır). Yönergeler bittikten sonra katılımcılardan önlerindeki bilgisayarın monitörünü açarak çalışmalara başlamaları istenmiştir. Katılımcılar önce deney prosedürünü anlayıp anlamadıklarını sınayan sorulara yanıt vermiş, yanlış verilen yanıtlar için program doğru cevabın ne olduğunu detaylıca açıklamıştır. Daha sonra, katılımcılar önce ilk çalışmayı (düzenleyici odak manipülasyonu) tamamlamışlardır. Birinci çalışmayı tamamladıktan sonra ikinci çalışma başlamadan önce katılımcıların çalışmaya katılan diğer kişilerle eşleştirilebilmeleri için kendilerine verilen dosyadaki kod numarasını yazmalarını isteyen bir ekran gelmiştir. Bu kod numarası katılımcı eşleşmelerinin inandırıcılığını sağlamanın yanında bireylerin deney verileriyle ön test verilerinin eşleşmesini de mümkün kılmaktadır. Takiben, katılımcılar ikinci çalışmayı (mahkumun ikilemi oyunu) yönergelere göre tamamlamıştır. Mahkumun ikilemi oyununu bir kez tamamladıktan sonra katılımcılara tanımlayıcı norm manipülasyonu yapılmıştır. Ardından katılımcılar mahkumun ikilemi oyununu bir kez daha ancak bu sefer farklı bir kişi ile oynamıştır. İkinci mahkumun ikilemi oyununun tamamlanmasını müteakip katılımcılara norm manipülasyonu kontrol ölçeği verilmiştir. Ardından katılımcıların duygu durumlarını ölçen bir ölçek uygulanmıştır. Takip eden ekranda katılımcılara düzenleyici odak manipülasyon kontrol sorusu sorulmuştur. Son olarak teşekkür, yorum ve bilgilendirme ekranına geçilmiştir. 


\section{Veri Analizi}

Tanımlayıcı Norm Manipülasyon Kontrolü. Manipülasyon kontrol sorularına verilen yanıtların ortalamaları kontrol (Ort. $=2.26, S=.72)$, bencil davranış normu (Ort. $=$ $1.98, S=.54)$ ve iş birliği normu (Ort. $=2.76, S=.46)$ gruplarında farklılaşmaktadır, $F(2,287)=26.85, p<.01$. Bonferoni düzeltmesi ile yapılan post-hoc analizlerde grup ortalamalarının her üçünün de birbirinden farklı olduğu görülmüştür. Bu bulgu, tanımlayıcı norm manipülasyonunun başarıya ulaştığına işaret etmektedir.

Düzenleyici Odak Manipülasyon Kontrolü. Gino ve Margolis’e (2011) göre kat1lımcıların gördükleri resmin içeriğini doğru hatırlamaları manipülasyonun gerçekleştiğinin, yani katılımcıların emniyet/güvenlik veya ilerleme/doyum ihtiyaçlarına dair veriyi zihinlerinde işlemden geçirdiğinin bir göstergesi olmaktadır. Çalışmada katılımcıların neredeyse tamamı resmin içeriğini (labirentin içinde bir fare ve peynir veya labirentin içinde bir fare ve onu yemeye çalışan bir yırtıcı kuş) doğru olarak hatırlamıştır. Dolayısıyla, mevcut yazın ışığında düzenleyici odak manipülasyonunun başarılı olduğu söylenebilir.

Keşifsel Analizler. Yapılan keşifsel analizlerde cinsiyetin etkileşimli etkileri $H 1$ açısından anlamlı olduğu için hipotez testinde cinsiyetin ana etkileri ve etkileşimli etkileri de dikkate alınmıştır. Ancak $H 2$ ve $H 3$ için cinsiyetin etkileşimli etkileri anlamlı olmadığ 1 için bu hipotezlerin testinde cinsiyetin yalnızca ana etkisine bakılmıştır. Diğer taraftan sosyoekonomik statü ve duygu durum değişkenlerinin ana etkileri tüm testlerde kontrol edilmiştir. Daha önce de belirtildiği üzere, istatistiksel gücü arttırmak için çalışmanın bağımsız değişkeni SDY sürekli bir değişken olarak işlemselleştirilmiştir. Bu nedenle, tüm hipotez testleri için çoklu regresyon analizi kullanılmıştır. Regresyon analizinde kategorik değişkenler kukla değişken şeklinde kodlandığında (örn., 1 ve 0) ve etkileşimli etkiler modele dahil edildiğinde, ana etkiler etkileşimli etkilerden bağımsız ve doğru bir şekilde hesaplanamamaktadır (Cohen, Cohen, West ve Aiken, 2003). Regresyonda değişkenlerin gerçek ana etkilerini görebilmek ve ana etkiler ile etkileşimli etkileri birbirinden ayırabilmek için kategorik değişkenler (cinsiyet, düzenleyici odak ve tanımlayıcı norm) basit etki kodlamasına (simple effect coding) tabi tutulmuştur (Cohen ve ark., 2003). Buna göre, cinsiyet kategorik değişkeni (H1) erkek için -1, kadın için +1 ; düzenleyici odak kategorik değişkeni $(H 1$ ve $H 3)$ ise önleme odağ $1+1$ ve yükselme odağ1 -1 olacak şekilde kodlanarak analizlere dahil edilmiştir. 
$H 2$ ve $H 3$ 'ün testinde üç seviyeden oluşan tanımlayıcı norm değişkeni için iki ayrı kategorik değişken tanımlanmış ve bu değişken için de etki kodlaması yapılmıştır (norm1= iş birliği normu koşulu (1) vs. bencil davranış normu koşulu (-1); kontrol koşulu $=0$ ); norm2 = kontrol koşulu (1) vs. bencil davranış normu koşulu (-1); iş birliği normu koşulu =0). Bu kodlama, bencil davranış normuna kıyasla, iş birliği normu ve kontrol koşullarında bireylerin iş birliği davranışlarının nasıl değiştiğini görmeye olanak vermiştir. Ayrıca, sürekli değişkenler kendi ortalamalarından çıkarılarak (merkezileştirilerek) analize sokulmuş, etkileşim terimleri bu işlemden sonra oluşturulmuştur. $H 1$, oyundaki ilk tur iş birliği davranışı değerleri; $H 2$ ve $H 3$ ise ikinci turdaki iş birliği davranışı değerleri ile test edilmiştir.

\section{BULGULAR}

\section{H1'in Testi}

SDY (toplum yanlısı, kendine yanlı) $x$ düzenleyici odak (önleme odaklı, yükselme odaklı) etkileşiminin mahkum ikileminde ilk turdaki iş birliği davranışına etkisini sınayan $H 1$ Tablo 2' de görülen doğrusal regresyon analizi ile test edilmiştir.

Tablo 2. H1'in Testine ait Regresyon Analiz Sonuçları

\begin{tabular}{|c|c|}
\hline Öngörücü değişkenler & Katsayılar \\
\hline Kesişim & $32.42(1.49)^{* *}$ \\
\hline \multicolumn{2}{|l|}{ Ana etkiler } \\
\hline SES & $.03(.92)$ \\
\hline Olumlu duygu durum & $1.00(2.35)$ \\
\hline Olumsuz duygu durum & $.61(2.84)$ \\
\hline Cinsiyet ${ }^{a}$ & $1.72(1.49)$ \\
\hline $\mathrm{SDY}^{\mathrm{b}}$ & $.12(.04)^{* *}$ \\
\hline Düzenleyici Odak c $^{\text {c }}$ & $.25(1.51)$ \\
\hline \multicolumn{2}{|l|}{ Etkileşim etkileri } \\
\hline Cinsiyet $x$ SDY & $-.05(.04)$ \\
\hline Cinsiyet $x$ Düz. Odak & $3.45(1.50)^{*}$ \\
\hline Düz. Odak $x$ SDY & $-.02(.04)$ \\
\hline Düz. Odak $x$ SDY $x$ Cinsiyet & $.11(.04)^{* *}$ \\
\hline$F$ test & $F(10,278)=3.15^{* *}$ \\
\hline$R^{2}$ & .10 \\
\hline \multicolumn{2}{|c|}{$\begin{array}{l}\text { Not. Bağımlı değişken birinci turdaki iş birliği davranışıdır. Standart hatalar par } \\
\text { içinde gösterilmiştir. } \\
\text { a Cinsiyet erkek }=-1 \text {, kadın }=1 \text { olarak kodlanmıştır. } \\
{ }^{\mathrm{b}} \text { SDY (Sosyal değer yönelimi) yüksek değer aldıkça bireyin toplum yanlılığı } \\
\text { artmaktadır. } \\
{ }^{\mathrm{c}} \text { Düzenleyici odak yükselme odağ } 1=-1 \text {, önleme odağ } 1=1 \text { olarak kodlanmıştır. } \\
{ }^{*} p<.05 * * p<.01\end{array}$} \\
\hline
\end{tabular}


Mevcut yazınla uyumlu olarak bireyin SDY açısı ile iş birliği davranışı arasında olumlu ilişki gözlenmiştir ( $\beta=.12, p<.01$ ). Buna göre bireylerin üç hafta önce ölçülen değer yönelimlerinde toplum yanlılıkları arttıkça mahkum ikileminde gösterdikleri iş birliği davranışları artmaktadır. Düzenleyici odağın iş birliği davranışı üzerindeki ana etkisi ise anlamlı değildir $(\beta=.25, p=.86)$. H1'de beklenenin aksine, düzenleyici odak (önleme odaklı, yükselme odaklı) $x$ SDY (toplum yanlısı, kendine yanlı) etkileşimi anlamlı bulunmamıştır $(\beta=-.02, p=.55)$.

\section{Cinsiyetin Rolü}

Tablo 2'de görüldügüü üzere cinsiyetin önemli etkileşimli etkileri gözlenmiştir. İlk olarak, cinsiyet (kadın, erkek) $x$ düzenleyici odak (önleme odaklı, yükselme odaklı) etkileşim terimi anlamlı bulunmuştur ( $\beta=3.45, p<.05)$. Düzenleyici odağın iş birliği davranışı üzerindeki etkisi kadınlarda ve erkeklerde ayrı regresyon eğimleri (basit eğimler) hesaplanarak incelenmiştir. Basit eğimlere bakıldığında, erkeklerde önleme odağının (yükselme odağına nazaran) iş birliği davranışını azalttığı $(B=-3.20, S H=2.05, p=$ $.12)$, kadınlarda ise tam tersi arttırdığ $1(B=3.70, S H=2.20, p=.09)$ görülse de basit eğimlerin anlamlılık düzeyine ulaşmadığı gözlenmiştir. Buna karşın, cinsiyetin iş birliği davranışı ile ilişkisi yükselme ve önleme odaklarında ayrı ayrı incelendiğinde önleme odağında kadınların erkeklere nazaran daha yüksek iş birliği davranışı gösterdikleri görülürken $(B=5.17, S H=2.11, p<.05)$ yükselme odağında ise cinsiyet ile iş birliği davranışı ilişkisi anlamlı bulunmamıştır $(B=-1.72, S H=2.12)$.

Diğer taraftan, $H 1$ cinsiyet değişkeni modele dahil edilerek test edildiğinde, düzenleyici odak (önleme odakl1, yükselme odakl1) $x$ SDY (toplum yanlısı, kendine yanlı) $x$ cinsiyet (kadın, erkek) üç yönlü etkileşim etkisi anlamlı bulunmuştur $(\beta=.11, p<.01$; $\Delta \mathrm{R} 2=.03$ ). Bu etkinin doğası incelendiğinde düzenleyici odak (önleme odakl1, yükselme odaklı) ve sosyal değer yönelimi (toplum yanlısı, kendine yanlı) etkileşiminin erkek katılımcılar arasında anlamlı olduğu görülmüş ( $B=-.13, S H=.05, p<.05)$, fakat kadınlar arasında anlamlı bulunmamıştır $(B=.10, S H=.06, p=.11)$. Erkekler arasındaki SDY (toplum yanlısı, kendine yanlı) $x$ düzenleyici odak (önleme odaklı, yükselme odaklı) etkileşiminin doğası, düzenleyici odağın iş birliği davranışına etkisine SDY'nin +1 ve -1 standart sapma değerlerinde ayrı ayrı bakılarak incelenmiştir. Buna göre, SDY açısı yüksek olduğunda (+1 standart sapma, toplum yanlılı̆g arttıkça), beklendiği gibi önleme odağının yükselme odağına kıyasla iş birliği davranışını azalttığı görülmüştür $(B=-8.22, S H=2.94, p<.01)$. SDY açısı düşük olduğunda $(-1$ standart sapma, toplum 
yanlılığı azaldıkça), düzenleyici odak ve iş birliği davranışı ilişkisi anlamlılığını yitirmektedir $(B=1.83, S H=2.82, p=.52)$. Bu bulgular $H 1$ 'de beklenen SDY (toplum yanlısı, kendine yanlı) $x$ düzenleyici odak (önleme odaklı, yükselme odaklı) etkileşim etkisini sadece erkekler için desteklemektedir. Tarif edilen üç yönlü etkileşim etkisi Şekil 3 a ve 3 b'de grafik olarak gösterilmektedir.

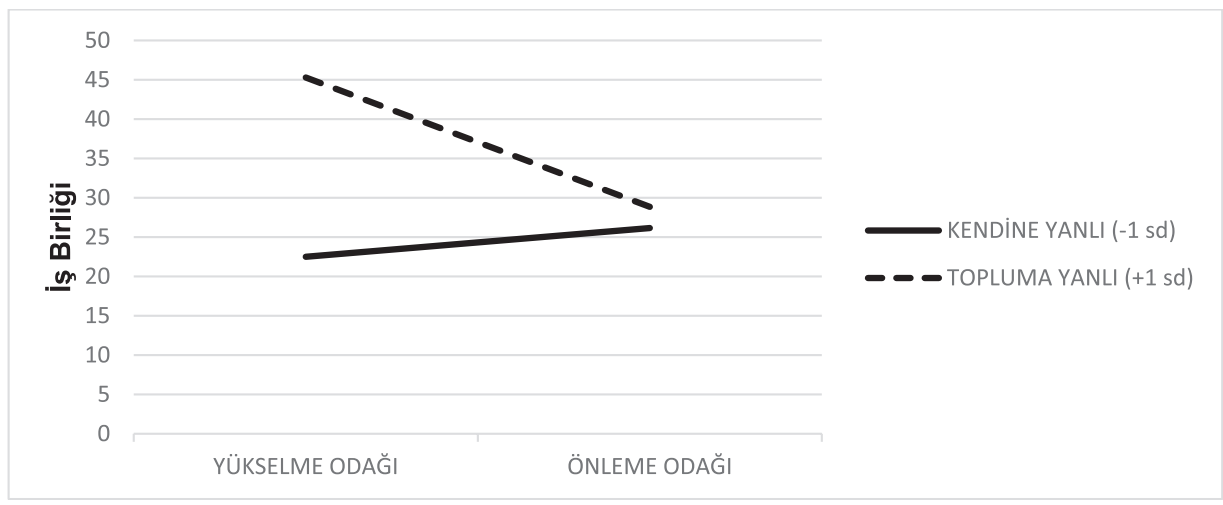

Şekil 3a. H1 Erkek Katılımcılar: SDY, Düzenleyici Odak ve İş Birliği İlişkisi

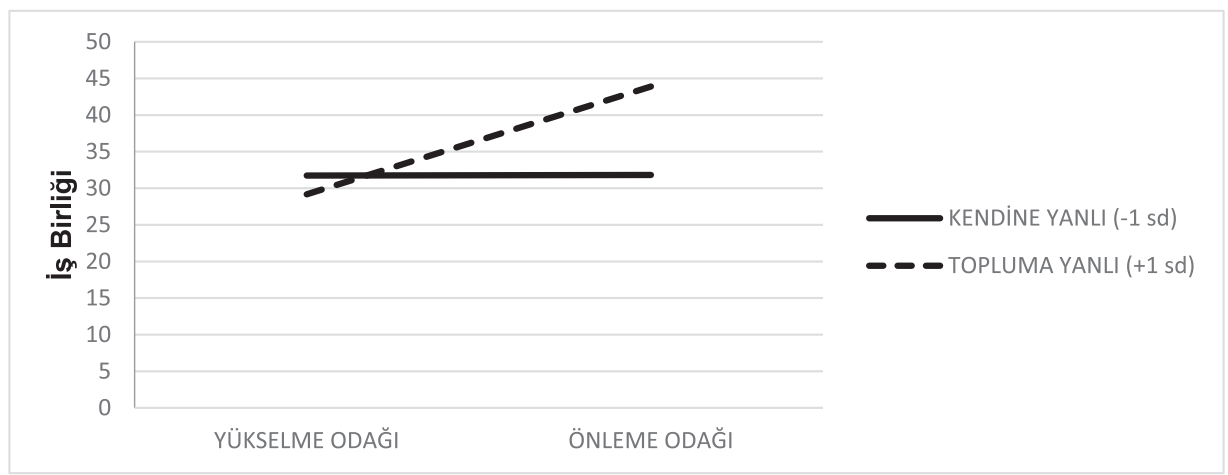

Şekil 3b. H1 Kadın Katılımcılar: SDY, Düzenleyici Odak ve İş Birliği İlişkisi

\section{$H 2$ ve $H 3$ 'ün Testi}

H2'de SDY (toplum yanlısı, kendine yanlı) $x$ tanımlayıcı norm (iş birliği normu, bencil davranış normu, kontrol) etkileşiminin $H 3$ 'te ise SDY (toplum yanlısı, kendine yanlı) $x$ düzenleyici odak (önleme odaklı, yükselme odaklı) $x$ tanımlayıcı norm (iş birliği normu, bencil davranış normu) etkileşiminin (ikinci turdaki) iş birliği davranışı üzerindeki etkileri incelenmiştir. Yapılan keşifsel analizlerde cinsiyetin etkileşimli etkileri hipotezler açısından anlamlı olmadığı için buradaki tüm analizlerde cinsiyetin yalnızca 
ana etkisi kontrol edilmiştir. Yine sosyoekonomik durumun ve duygu durumunun ana etkileri analizlerde kontrol edilmiştir. Sonuçlar Tablo 3’te gösterilmektedir.

Tablo 3. H2 ve H3'ün Testine ait Regresyon Analizi Sonuçları

\begin{tabular}{lc}
\hline Öngörücü değişkenler & Katsayılar $^{*}$ \\
\hline Kesişim & $35.70(1.61)^{* *}$ \\
\hline Ana etkiler & $.38(1.02)$ \\
\hline SES & $2.07(2.59)$ \\
Olumlu duygu durum & $2.75(3.10)$ \\
Olumsuz duygu durum & $1.75(1.64)$ \\
Cinsiyet $^{\text {a }}$ & $.14(.04)^{* *}$ \\
SDY & $2.49(1.63)$ \\
Düzenleyici Odak ${ }^{\text {b }}$ & $7.25(2.27)^{* *}$ \\
Norm1(Bencil davranış vs. iş birliği) ${ }^{\text {c }}$ & $-2.47(2.34)$ \\
Norm2 (Bencil davranış vs. Kontrol) $^{\text {d }}$ & \\
\hline Etkileşim etkileri & $.15(.06)^{*}$ \\
\hline Norm1 $x$ SDY & $-.06(.06)$ \\
Norm2 $x$ SDY & $-.06(.04)$ \\
Düz. Odak $x$ SDY & $1.20(2.28)$ \\
Düz. Odak $x$ Norm1 & $1.08(2.29)$ \\
Düz. Odak $x$ Norm2 & $-.09(.06)$ \\
Düz. Odak $x$ SDY $x$ Norm1 & $-.04(.06)$ \\
Düz. Odak $x$ SDY $x$ Norm2 & $F(15,273)=2.63 * *$ \\
\hline test & .13 \\
$R^{2}$ &
\end{tabular}

Not. Bağımlı değişken ikinci turdaki iş birliği davranışıdır. Standart hatalar parantez içinde gösterilmektedir.

a Cinsiyet: erkek $=-1$, kadın $=1$ olarak kodlanmıştır.

${ }^{\mathrm{b}}$ Düzenleyici odak: yükselme $=-1$, önleme $=1$ olarak kodlanmıştır.

${ }^{\mathrm{c}}$ Norm 1: kontrol $=0$, bencil davranıș $=-1$, iş birliğ $\mathrm{i}=1$ olarak kodlanmıștır.

${ }^{\mathrm{d}}$ Norm 2: kontrol $=1$, bencil davranıș $=-1$, iş birliğ $\mathrm{i}=0$ olarak kodlanmıștır.

$* p<.05, * * p<.01$.

$\mathrm{Bu}$ analizlerde öncelikli amaç tanımlayıcı normun iş birliği olduğu durumla tanımlayıcı normun bencil davranış olduğu durumu karşılaştırmak olduğundan norm1 değişkeni dikkate alınmalıdır ${ }^{1}$. Beklendiği gibi, SDY (toplum yanlısı, kendine yanlı) $x$ norm1 (iş birliği normu, bencil davranış normu) etkileşim terimi anlamlı bulunmuştur $(\beta=.15$, $p<.05)$. Şekil 4 'te görüleceği üzere, tanımlayıcı normun iş birliği olması bencil davranış olmasına kıyasla toplum yanlısı bireylerin iş birliği davranışını anlamlı düzeyde art-

1 Çalışmanın odak noktası olmasa da Tablo 3'teki diğer bulgulara da değinmek fayda sağlayacaktır. Tablo 3'te görüldüğü üzere tanımlayıcı norm iş birliği olduğu durumda tanımlayıcı normun bencil davranış olduğu duruma kıyasla bireyler daha fazla iş birliği davranışı gösterme eğilimindedir $(\beta=7.25, p<.01)$. Buna karşılık, belirli bir norm olmadığı kontrol durumu ile tanımlayıcı normun bencil davranış olduğu durum arasında bireylerin iş birliği davranışı bakımından bir fark yoktur $(\beta=-2.47, p=.30)$. Bu bulgu bireylerin tanımlayıcı normların açık olmadığı durumda bencil davranma eğiliminde olduğuna işaret etmektedir. Tablo 3'te SDY'nin ana etkisi de göze çarpmaktadır $(\beta=.14, p<.01)$. Buna göre, bireyin toplum yanlılığı arttıkça ikinci turda eşleştikleri kişisyle iş birliği artmaktadır. 
tırırken $(B=12.93, S H=3.25, p<.01)$, kendine yanlı bireylerin iş birliği davranışını etkilememiştir $(B=1.57, S H=3.35, p=.61)$. Bu bulgu $H 2$ ile uyumludur. Diğer taraftan, beklenenin aksine, düzenleyici odak (önleme odaklı, yükselme odaklı) $x$ SDY (toplum yanlısı, kendine yanlı) $x$ norm1 (iş birliği normu, bencil davranış normu) üç yönlü etkileşiminin iş birliği davranışı ile ilişkisi anlamlı değildir $(\beta=-.09, p=.16)$. Buna göre, $H 3$ desteklenmemiştir. Bu bulgulara göre, tanımlayıcı normların sosyal değer yönelimi ile etkileşerek iş birliği davranışını hem önleme odağında hem de yükselme odağında eşit düzeyde etkilediği görülmektedir.

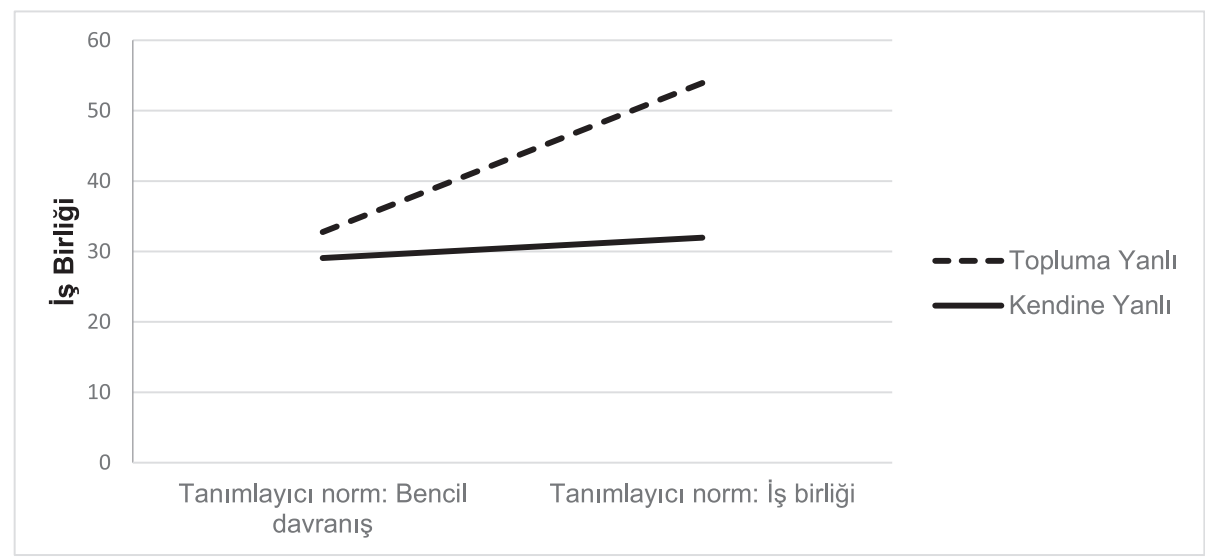

Şekil 4. Sosyal Değer Yönelimi, Tanımlayıcı Norm ve İş Birliği İlişkisi

\section{TARTIŞMA}

Bu çalışma, $H 1$ 'de öngörülen düzenleyici odak $x$ sosyal değer yönelimi etkileşiminin iş birliği davranışı üzerindeki etkisinin cinsiyete göre biçimlendirildiğini, yani düzenleyici odak $x$ sosyal değer yönelimi $x$ cinsiyet üçlü etkileşim etkisinin görüldüğünü ortaya koymuştur. Buna göre, toplum yanlısı bireylerin önleme odağı aktif iken (yükselme odağına kıyasla) mahkum ikilemi oyununda daha az iş birliği davranışı göstereceği beklentisi sadece erkekler için desteklenmiştir. Kadın katılımcılar için ise düzenleyici odak $x$ sosyal değer yönelimi etkileşiminin iş birliği davranışı üzerindeki etkisi anlamlı bulunmamıştır. Yine $H 1$ ile uyumlu olarak kendine yanlı bireylerde düzenleyici odak ne kadınların ne de erkeklerin iş birliği kararını etkilemiştir. Dahası, bulgular tanımlayıcı norm $x$ sosyal değer yönelimi etkileşiminin H2 ile uyumlu bir şekilde anlamlı olduğunu ortaya koymaktadır. Buna göre, toplum yanlısı bireylerin iş birliği davranışı, ortamdaki 
belirgin tanımlayıcı normlardan etkilenmektedir. Buna karşın, kendine yanlı bireyler ise her iki tanımlayıcı norm durumunda da benzer ve nispeten düşük iş birliği davranışı göstermiştir. $H 3$ ’te test edilen sosyal değer yönelimi $x$ düzenleyici odak $x$ tanımlayıcı norm üçlü etkileşiminin iş birliği davranışına etkisi ise anlamlı bulunmamıştır. Dolayısıyla, tanımlayıcı normların toplum yanlısı bireylerin iş birliği davranışı üzerindeki etkisinin düzenleyici odaktan bağımsız olduğu görülmektedir. Son olarak, mevcut yazınla uyumlu olarak mahkum ikilemi oyununun her iki turunda da sosyal değer yöneliminin iş birliği davranışı üzerinde ana etkisi görülmüştür. Beklendiği gibi, toplum yanlısı sosyal değer yöneliminde olan bireyler kendine yanlılara göre daha yüksek iş birliği davranışı göstermiştir. Bu bulguların teoriye ve uygulamaya önemli katkıları mevcuttur.

Sosyal değer yönelimlerinin (SDY) genel olarak sosyal ikilem durumlarında ve özellikle en sık karşılaşılan ikilem yapısı olan mahkum ikileminde iş birliği ile ilişkisi mevcut alan yazında çalışılmıştır (Meta-analiz çalışmaları için bkz. Balliet ve ark., 2009; Pletzer ve ark., 2018). Diğer taraftan, geçmiş çalışmaların önemli bir kısmı SDY ve iş birliği davranışını aynı anda ölçmekte, dolayısıyla SDY’nin kişilik özelliği olarak etkisi yöntem varyansının etkisinden ayırt edilememektedir (Balliet ve ark., 2009). Bu çalışma ise SDY'yi deneyden haftalar önce ölçerek SDY'nin kişilik özelliği olarak etkisini daha doğru bir şekilde ortaya koymaktadır. Bulgular ışığında, mevcut alan yazınla uyumlu olarak, bireyin toplum yanlılığı arttıkça mahkum ikilemindeki iş birliği davranış düzeyi yükselmektedir.

Sosyal ikilemler ve iş birliği alan yazınında önleme odağının etkilerini doğrudan yükselme odağı ile karşılaştıran ve bu nedenle düzenleyici odak teorisi ile uyumlu deneysel çalışmalar mevcut değildir. Buna göre mevcut çalışmanın önemli bir katkısı, her iki düzenleyici odak türünün, alan yazında en çok incelenen sosyal ikilem türü olan mahkum ikileminde iş birliği davranışı üzerindeki karşılaştırmalı etkisini teoriyle uyumlu bir açıdan incelemesidir. Dahası, düzenleyici odağın iş birliği davranışı ile ilişkisini inceleyen önceki çalışmalar birbiri ile çelişen bulgular ortaya koymuştur. Örneğin bir çalışma kronik önleme odağının iş birliği davranışını azalttığını (Keller ve Pfattheicher, 2011), başka bir çalışma ise önleme odağına sahip bireylerin iş birliği yapmaya daha motive olduğunu ve iş birliği göstermeye yanaşmayan kişileri cezalandırdığını (Pfattheicher ve Keller, 2013) göstermiştir.

Bu çelişkili bulguların bir nedeni önleme odağının etkisinin yükselme odağına k1- 
yasla incelenmemesi olabilecekken, diğer bir neden ise düzenleyici odağın iş birliği davranışı üzerindeki etkisinin diğer faktörler tarafından biçimlendirilmesi olabilir. Nitekim, $H 1$ 'e dair bulgular düzenleyici odağın sadece toplum yanlısı erkekler arasında iş birliği davranışını etkilediğini göstermektedir. Erkekler arasında görülen sosyal değer yöneliminin biçimlendirici etkisi, Pruitt ve Kimmel'in (1977) hedef-beklenti yaklaşmıyla uyumludur. Bu yaklaşıma göre, sadece iş birliği yöneliminde olanların etkileşime girdikleri birey(ler)in davranışlarına dair beklentileri ve dolayısıyla iş birliği davranışları çevresel/durumsal faktörlerden etkilenmektedir. Bencil bireyler ise bencil davranış Nash denge noktasına ${ }^{2}$ göre karşıdaki kişinin hamlesinden bağımsız çıkar maksimizasyonu getirdiği için her durumda bencil davranmakta; beklentilerini ise sadece bu davranışlarını gerekçelendirecek biçimde ve çevresel faktörlerden etkilenmeden şekillendirmektedirler (Kuhlman ve Wimberley, 1976). Bu çalışmada da, bu yaklaşımla uyumlu olarak toplum yanlılı̆̆ azaldıkça (kendine yanlı yönelim arttıkça) bireylerin iş birliği davranışının durumsal manipülasyonlardan daha az etkilendiği görülmektedir.

Çalışmanın bulguları erkeklerin kadınlardan daha az iş birliği davranışı gösterdiği savını (Simpson, 2003) dolaylı olarak desteklemektedir. Hatırlanacağı üzere, Tablo 2'de H1'in testinde önleme odağı durumunda erkeklerin iş birliği davranışı kadınlara kıyasla daha düşüktür. Ancak yükselme odağı durumunda ise böyle bir fark görülmemiştir. Buna göre, erkeklerin önleme odağı koşulunda kadınlara nazaran tehlikeye (bu çalışmada, sömürülme ihtimaline) daha fazla tepki verdiği ve daha düşük iş birliği yaptığı söylenebilir. Sadece toplum yanlısı bireyler üzerinde yapılan ek analiz de önleme odağ durumunda yukarıdaki cinsiyet etkisini desteklemektedir ${ }^{3}$. Dolayısıyla, bu mantıktan yola çıkarak ve kadınlarla erkeklerin yükselme odağında verdiği tepkinin benzer olduğunu göz önüne alarak şu yargıya varılabilir: Toplum yanlısı erkekler önleme odağı koşulunda tehlikeye daha fazla tepki verdiklerinden, bu kişilerde önleme ve yükselme odağı arasındaki iş birliği davranış düzeyi farkı anlamlı çıkmaktadır. Öte taraftan kadınlar önleme odağında tehlikeye daha az tepki verdiklerinden kadınlarda önleme ve yükselme odağı arasındaki iş birliği davranış düzeyi farkı daha düşük ve anlamsız çıkmış olabilir. Gelecek çalışmalarda cinsiyetin bu biçimlendirici etkisinin Türk kültürüne özgü olup olmadığının ve yukarıda bahsedilen mekanizma ve başka olası mekanizmaların incelenmesi fayda sağlayacaktır. Diğer taraftan, cinsiyetin bu etkileşimli etkisi diğer hipo-

2 Nash denge noktası, diğer kişinin kararları ve/veya stratejileri sabit tutulduğunda, bireyin getirisini maksimize ettiği noktadır.

$3(B=7.52, S H=2.53, p<.05)$. 
tezlerin testinde görülmemişsir. Bunun bir sebebi, Ortmann ve Tichy'nin (1999) belirttiği gibi cinsiyet etkisinin tekrarlı deneylerin ilk turunda daha fazla ortaya çıkması ve diğer turlarda azalması olabilir.

Bulgular toplum yanlısı bireylerin iş birliği davranışlarının bağlamdaki tanımlayıcı normlardan etkilendiğini ve bu etkinin düzenleyici odaktan bağımsız olduğunu göstermektedir. Şekil 4'te gösterilen etki mahkum ikileminde bencil davranışın baskın strateji olması ve kar maksimizasyonu sağlaması ile uyum göstermektedir (Kollock, 1998). Toplum yanlısı motivasyona sahip bireyler ise ancak ve ancak diğer insanların iş birliği yapacağını beklediklerinde (tanımlayıcı norm iş birliğini işaret ettiğinde) iş birliği davranışı göstermektedir (Pruitt ve Kimmel, 1977). Dolayısıyla bulgular, tanımlayıcı normun bencil davranış olduğu durumda toplum yanlısı bireylerin sömürülme korkusu ile düşük iş birliği davranışı gösterecekleri açıklamasıyla uyumludur. Mevcut bulgularla uyumlu olarak, iki farklı deney çalışmasında (Van Lange ve Kuhlman, 1994) toplum yanlısı kişilerin dürüst olmayan kişilere kıyasla dürüst kişilerden daha çok iş birliği beklediği (Deney 1) ve daha çok iş birliği davranışı gösterdiği (Deney 2), kendine yanlıların beklentilerinin ve davranışlarının ise bu bilgiden daha az etkilendiği bulunmuştur.

Bulguların önemli pratik katkılar sağlama potansiyeli de vardır. İlk olarak, tanımlayıcı normlar ile ilgili bulgu, toplum yanlısı bireylerin iş birliğini kaybetmemek için toplumun genelini iş birliği davranışı göstermeye yönlendirecek uygulamaların önemine işaret etmektedir. Bu bulgudan ve tanımlayıcı normların ana etkisinden yola çıkarak, normlara uymayı sağlayan çeşitli yaptırım sistemleri geliştirilerek veya var olanlar güçlendirilerek (özellikle toplum yanlısı bireylerin) iş birliği davranışının arttırılması sağlanabilir. Yine bulgulara göre, sosyal ikilem olarak kavramsallaştırılan kan bağışı ve çevre duyarlılı̆̆ı gibi toplum için önemli davranışların birçok kişi tarafından gösterildiğine dair algı yaratmak, toplum yanlısı yönelime sahip bireyleri böyle davranışları daha fazla göstermeye yöneltebilir.

Birinci hipoteze dair bulgular özellikle toplum yanlısı erkeklerin, sosyal ilişkilerden bağımsız alanlarda emniyet ve güvenlik ihtiyaçlarının aktif olması durumunda düşük iş birliği davranışı gösterebileceğine işaret etmektedir. Bunun için ailede ve eğitim kurumlarında bireylerin güvenlik ve emniyet ihtiyaçlarından (önleme odağı) ziyade başarma ve ilerleme ihtiyaçlarını (yükselme odağı) ön plana çıkaracak politikalar geliştirilerek toplum yanlısı bireylerin güveni ve iş birliği davranışı arttırılabilir. 
Çalışma, alan yazınla uyumlu bir şekilde (bir meta-analiz çalışması için bkz. Balliet ve ark., 2009), haftalar öncesinde ölçümlenen sosyal değer yöneliminin bireylerin her iki turda gösterdiği iş birliği davranışı ile ilişkili olduğunu göstermiştir. Sosyal değer yönelimi (SDY) çalışmada manipüle edilen bir değişken olmadığı için bu bulgu neden-sonuç ilişkisi bağlamında kesin kanıt sağlamamaktadır. Ancak, SDY'nin ölçümünün deney uygulamasından zamansal ayrımı SDY ve iş birliği arasındaki ilişkinin bir takım kirletici etmenlere maruz kalma riskini azaltmakta ve araştırma deseninin geçerliliğine katkı sağlamaktadır. Dolayısıyla, bu bulgu toplum yanlısı bireyler yetiştirmenin toplum içinde iş birliğini arttırmaya katkı sağlayabileceğine işaret etmektedir. Çocukluk çağında ailenin ve eğitim kurumlarının toplum yanlısı bireyler yetiştirmede önemli bir yeri olduğu söylenebilir. Geçmiş çalışmalar çocuğun erken dönemde yaşıtlarıyla (kardeş, arkadaş) paylaşımda bulunmasının ve anneye güvenli bağlanma (secure attachment) yaşamasının toplum yanlısı motivasyonun gelişmesindeki önemine işaret etmektedir (Van Lange ve ark., 1997). Çocukların paylaşımda bulunacağı ortamlar sağlanması ve çalışan annelere çocuklarına daha fazla vakit ayırabilecekleri koşulların yaratılması (örn., doğum izni süresinin AB ülkelerindeki sürelere çıkarılması) bireylerde toplum yanlısı bir yönelimin geliştirilmesine katkı sağlayabilir.

Diğger taraftan, ön testte toplanan sosyal değer yönelimleri verileri incelendiğinde toplum yanlısı birey sayısının batı örneklemlerine kıyasla az ve rekabetçi birey sayısının ise batı örneklemlerine kıyasla fazla olduğu görülmüştür. Bu veriler sadece bir üniversitenin öğrencilerinden toplanmış olsa da örneklem büyüklüğü ve farklı birimlerden oluşan dağılım dikkate alındığında bu bulgu dikkat çekicidir. Dahası, üç hafta önce ölçümlenen bu değer yönelimlerinde yanlı (hatalı) bir ölçümleme olsaydı, bireylerin sosyal değer yönelimleri daha sonra yürütülen bir deneyde iş birliği davranışını alan yazına uyumlu bir şekilde etkilemeyebilirdi. Her ne kadar sosyal değer yönelimi dağ1lımları ile ilgili bulguların desteklenmesi için mutlaka daha geniş kapsamlı çalışmalar gerekse de, bulgular genel olarak Türkiye'de birbirini tanımayan kişiler arasındaki iş birliği davranışının düşüklüğü (Herrmann ve ark., 2008) ile ilişkili bir başka faktörün bireylerin sosyal değer yönelimleri olabileceğine işaret etmektedir. Sosyal değer yönelimleri ölçeğinin standart talimatlarında bireyin hiç tanımadığı ve hiç görmeyeceği başka bir bireyin kazanımlarına ilişkin tercihleri sorulmaktadır. Türkiye gibi yakın ilişkiler üzerine kurulu bir kültürde bireyler tanımadıkları kişileri dış grup olarak görüp, onlara karşı daha olumsuz bir tutum (rekabetçi yönelim, düşük güven vb.) sergiliyor olabilir. 
Rekabetçi değer yönelimi batı toplumlarında anti sosyal olarak görülmektedir (Liebrand ve McClintock, 1988). Burada rekabetçi değer yöneliminin rekabet kültürel değeri ile karıştırılmaması gerekmektedir. Rekabet kültürel değeri olan toplumlarda, rekabetin gerekli olduğu durumlarda (örn., bir tarafın kazanırken diğerinin mutlaka kaybedeceği durumlarda) bireylerin rekabete bakış açıları olumludur ve rekabet desteklenir (Hayward ve Kemmelmeier, 2007). Bireyler böyle durumlardan kaçınmazlar. Ancak, rekabetçi sosyal değer yönelimi rekabetin şart olmadığı, hatta iş birliği davranışı göstermenin ortak çıkarı maksimize ettiği durumlarda (örn., sosyal ikilem durumlarında), kişilerin kendi kazanımları ile diğerlerinin kazanımları arasındaki pozitif farkı maksimize etme amacını ifade eder (Pletzer ve ark., 2018). Rekabetçi sosyal değer yönelimi, bu nedenle, kamusal kaynakların etkin kullanılmasını engeller (Balliet ve ark., 2009). Çalışmada elde edilen bulgular 1şığında düşük iş birliği davranışı düzeyi ve sosyal değer yönelimleri arasındaki ilişkinin gelecekte daha genellenebilir örneklemler üzerinde incelenmesi gerekmektedir.

Her çalışmada olduğu gibi bu çalışmada da bazı kısıtlılıklar vardır. Öncelikle, her ne kadar deneyde kullanılan düzenleyici odak manipülasyonu alan yazında kullanılan geçerli bir yöntem olsa da çalışmanın başka manipülasyon yöntemleri ile tekrarlanması sonuçların genellenebilirliğine katkı sağlayacaktır. Örneğin, yükselme odağını (doyum ve ilerleme ihtiyacını) aktifleştirmek için bireylere gelecekteki idealleri ve arzularını, önleme odağını (güvenlik ve emniyet ihtiyacını) aktifleştirmek için ise bireylerin gelecekte yapmakla yükümlü oldukları sorumlulukları ve görevlerini sormak suretiyle bireylerin düzenleyici odağı durumsal olarak hazırlanabilir (Bkz. Higgins, 1997). Bundan başka, düzenleyici odak durumsal olarak değişebildiği gibi kişiler arası farklılık gösteren bir kişilik özelliği (treyt) olarak da karşımıza çıkmaktadır. Alan yazındaki çalışmalar bireylerin sahip oldukları kronik düzenleyici odak ile durumsal olarak hazırlanan düzenleyici odağın benzer sonuçlar ortaya koyduğunu gösteriyor olsa da (Higgins, 1998) bireylerin baskın kronik düzenleyici odaklarının başka bir kişilik özelliği olan sosyal değer yönelimleri ile etkileşiminin iş birliği davranışına etkisinin gelecek çalışmalar tarafından araştırılması buradaki bulguların genellenebilirliğini arttıracaktır.

Ayrıca, çalışmada Türkiye'de bir üniversitenin öğrencilerinin birçok fakültesinden rassal olarak belirlenen bir öğrenci kitlesine ön test için ulaşılmış, ön test katılımcıları arasından ise sosyal değer yönelimlerinin dağılımı dengeli olacak şekilde farklı birimlerden kişiler deneye davet edilmiştir. Bulguların Türk örneklemleri kullanan diğer ça- 
lı̧̧maların bulguları (Balliet ve Van Lange, 2013; Herrmann ve ark., 2008) ile uyumlu olması örneklem seçiminin önemli bir sorun teşkil etmediğine işaret etmektedir. Çalışmalarda ağırlıklı olarak öğrenci örneklemlerinden yararlanılması aynı zamanda bulguların ağırlıklı olarak öğrenci örneklemi kullanılan uluslararası çalışmalarla karşılaştırılmasını da kolaylaştırmaktadır. Ancak, gelecekte Türkiye'nin farklı üniversitelerinden araştırmacıların koordinasyonu ile daha genellenebilir bir örneklem üzerinde bu çalışmanın tekrar edilmesi mevcut bulguların geçerliliğini ve güvenilirliğini güçlendirecektir.

Bu çalışmada sosyal değer yönelimi ölçümü için alan yazında başarıyla geçerliği test edilmiş ve güvenilir bir ölçek olan çember ölçeği kullanılmıştır (Liebrand, 1984). Çalışmanın hipotezleri kendine yanlı kişiler ve toplum yanlısı kişiler arasındaki farka odaklandığ 1 için bu ölçeğin kullanılması uygun olmakla birlikte alan yazında bulunan diğer ölçüm araçlarının kullanılması bu çalışmadaki bulguların geçerliliğine katkı sağlayacaktır. Dahası, Murphy, Ackermann ve Handgraaf (2011) tarafından geliştirilen kaydırmalı (slider) ölçek gibi bir aracın kullanılması durumunda çember ölçeğinin temsil etmediği sosyal değer yönelimlerinin etkisini görmek mümkün olacaktır. Buna göre toplum yanlısı değer yönelimi altında yer alan ortaklaşa toplam getiriyi maksimize etme (joint gain maximization) ve çıktılar arasındaki eşitsizliği minimize etme (inequality aversion) motivasyonu açısından düzenleyici odak ile etkileşimin iş birliği davranışı üzerindeki etkisini araştırmak ilginç sonuçlar doğurabilir.

Araştırmada sosyal ikilem durumlarındaki iş birliği davranışını ölçmek için yine alan yazında çok kez uygulanan mahkumun ikilemi oyunu kullanılmıştır (Camerer, 2011). Çalışmanın deneysel deseni gereği böyle bir araç kullanılmış olmakla birlikte bulguların gerçek hayattaki karşılı̆̆ının diğer iş birliği davranışları göz önünde bulundurularak test edilmesi ilgi çekici bir gelecek araştırma konusu olabilir. Örneğin, gerçek hayattaki sosyal ikilem durumlarındaki iş birliği davranışını gösteren kan bağışı yapılması, çevrenin ve ortak kaynakların korunması için destek verilmesi gibi davranışlar üzerine bireylerin kronik düzenleyici odakları ve sosyal değer yönelimlerinin etkileşimli etkisinin test edilmesi bulguların pratik değerine katkı sağlayabilir.

Gelecek çalışmalar açısından bir diğer ilginç araştırma sorusu tanımlayıcı normların çerçevelendirmesi (framing) olabilir. Mesaj çerçevelendirme (message framing) alanındaki çalışmalar bireyin motivasyonel eğilimleri ile uyumlu şekilde çerçevelendirilen 
mesajların organ bağışı, para bağışı, çevresel duyarlılık gösterme (örn., geri dönüşüm yapma), bireysel sağlık için harekete geçme (kanser tarama testi yapma, diş ipi kullanma, sağlıklı yiyecek tüketme) gibi davranışları olumlu şekilde tetikleyebildiğini (Das, Kerkhof ve Kuiper, 2008; Davis, 1995; Godinho, Updegraff, Alvarez ve Lima, 2017; Rothman ve Salovey, 1997) ve bireylerin ekonomik oyunlardaki davranışlarını etkileyebildiğini (Elliott ve Hayward, 1998) göstermektedir. Örneğin, bireylere ulaştırılan mesajlarda yükselme odağı için kazanım-çerçeveli (gain-framed), önleme odağı için kayıp-çerçeveli (loss-framed) ifadelerin kullanılması istenilen davranışa olumlu etki edebilir (Uskul, Sherman ve Fitzgibbon, 2009). Benzer şekilde toplum yanlısı bireylere ulaştırılan mesajlarda istenilen davranışın bireysel kazanıma kıyasla toplumsal kazanıma etkisinin çerçevelendirilmesi istenilen yönde davranışların daha fazla sergilenmesine katkı sağlayabilir (Van Andel, Tybur ve Van Lange, 2016). Buradan yola çıkarak çalışmada etkisi test edilen tanımlayıcı normların, bireylerin düzenleyici odakları ve/ veya sosyal değer yönelimlerine göre çerçevelendirilmesi bireylerin iş birliği davranış1nı olumlu yönde etkileyebilir.

Sonuç olarak, bu deney çalışması, bireylerin haftalar önce ölçümlenen sosyal değer yönelimlerinin bireyin mahkum ikilemi yapısına sahip sosyal ikilem durumlarındaki iş birliği davranışını öngördüğüne işaret etmektedir. Dahası, toplum yanlılığı yüksek bireylerde (özellikle erkeklerde) önleme odağının durumsal olarak hazırlanması yükselme odağına kıyasla iş birliği davranışını azaltmaktadır. Diğer taraftan, bireylerin toplum yanlılığı arttıkça bireylerin iş birliği davranışı tanımlayıcı normlardan etkilenmektedir. Buna göre, ortamdaki tanımlayıcı norm iş birliğini işaret ettiğinde toplum yanlısı bireylerin iş birliği davranışı, tanımlayıcı normun belirgin olmadığı veya bencil davranışı işaret ettiği duruma göre daha yüksek olmaktadır. Çalışma, düzenleyici odak ve tanımlayıcı normlar gibi durumsal faktörlerin toplum yanlısı bireylerin iş birliği davranışı için önemini göstermektedir. 
Etik Komite Onayı: Bu çalışma bir ulusal proje kapsamında yürütülmüş olup yürütücünün bağlı olduğu kurumdan etik kurul onay belgesi alınmıştır.

Hakem Değerlendirmesi: Dış bağımsız.

Yazar Katkıları: Çalışma Konsepti/Tasarım - G.K., S.E.; Veri Toplama- - G.K., S.E.; Veri Analizi/Yorumlama- - G.K., S.E.; Yazı Taslağ1- - G.K., S.E.; İçeriğin Eleştirel İncelemesi- - G.K., S.E.; Son Onay ve Sorumluluk- - G.K., S.E. Çıkar Çatışması: Yazarlar çıkar çatışması bildirmemiştir.

Finansal Destek: Bu çalışma, TÜBİTAK (proje no: 114K324) tarafından desteklenen ve Dr. Gökhan Karagonlar'ın yürütücülüğünü üstlendiği bilimsel bir proje kapsamında gerçekleştirilmiştir.

Ethics Committee Approval: This study was carried out within the scope of a national project and an ethics committee approval certificate was obtained from the institution to which the executive is affiliated.

Peer-review: Externally peer-reviewed.

Author Contributions: Conception/Design of Study- G.K., S.E.; Data Acquisition- - G.K., S.E.; Data Analysis/ Interpretation- - G.K., S.E.; Drafting Manuscript- - G.K., S.E.; Critical Revision of Manuscript- - G.K., S.E.; Final Approval and Accountability- - G.K., S.E.

Conflict of Interest: The authors have no conflict of interest to declare.

Grant Support: This work was supported by TUBITAK (project no: 114K324) and Dr. It was carried out within the scope of a scientific project led by Gökhan Karagonlar.

\section{Kaynakça/References}

Adler, N. E., Epel, E. S., Castellazzo, G. ve Ickovics, J. R. (2000). Relationship of subjective and objective social status with psychological and physiological functioning: Preliminary data in healthy, White women. Health Psychology, 19(6), 586-592.

$\mathrm{Au}, \mathrm{W}$. T. ve Kwong, J. Y. Y. (2004). Measurements and effects of social-value orientation in social dilemmas: A review. R. Suleiman, D. V. Budescu, I. Fischer ve D. M. Messick (Ed.), Contemporary psychological research on social dilemmas içinde (s. 71-98). USA: Cambridge University Press.

Aydın, M. Ş. (2021). 13-70 aylık çocuklarda prososyal davranışlar: Doğal gözlem çalışması. Psikoloji Çalışmaları -Studies in Psychology. Advance Online Publication

Baas, M., De Dreu, C. K. ve Nijstad, B. A. (2011). When prevention promotes creativity: The role of mood, regulatory focus, and regulatory closure. Journal of Personality and Social Psychology, 100(5), 794-809.

Balliet, D., Parks, C. ve Joireman, J. (2009). Social value orientation and cooperation in social dilemmas: A Meta-analysis. Group Processes \& Intergroup Relations, 12(4), 533-547.

Balliet, D. ve Van Lange, P. A. (2013). Trust, punishment, and cooperation across 18 societies: A metaanalysis. Perspectives on Psychological Science, 8(4), 363-379.

Batson, C. D. (1991). The altruism question: Toward a social-psychological answer. Hillsdale, NJ: Lawrence Erlbaum

Bless, H., Clore, G. L., Schwarz, N., Golisano, V., Rabe, C. ve Wölk, M. (1996). Mood and the use of scripts: Does a happy mood really lead to mindlessness?. Journal of Personality and Social Psychology, 71(4), 665-679.

Bogaert, S., Boone, C. ve Declerck, C. (2008). Social value orientation and cooperation in social dilemmas: A review and conceptual model. British Journal of Social Psychology, 47(3), 453-480.

Bogaert, S., Boone, C. ve van Witteloostuijn, A. (2012). Social value orientation and climate strength as moderators of the impact of work group cooperative climate on affective commitment. Journal of Management Studies, 49(5), 918-944.

Boone, C., Declerck, C. ve Kiyonari, T. (2010). Inducing cooperative behavior among proselfs versus 
prosocials: The moderating role of incentives and trust. Journal of Conflict Resolution, 54(5), 799824.

Brizi, A., Giacomantonio, M., Schumpe, B. M. ve Mannetti, L. (2015). Intention to pay taxes or to avoid them: The impact of social value orientation. Journal of Economic Psychology, 50, 22-31.

Caldwell, M. D. (1976). Communication and sex effects in a five-person prisoner's dilemma game. Journal of Personality and Social Psychology, 33, 273-80.

Camerer, C. F. (2011). Behavioral game theory: Experiments in strategic interaction. USA: Princeton University Press.

Chen, X. P. ve Bachrach, D. G. (2003). Tolerance of free-riding: the effects of defection size, defection pattern, and social orientation in a repeated public goods dilemma. Organizational Behavior and Human Decision Processes, 90(1), 139-147.

Cialdini, R. B. (2003). Crafting normative messages to protect the environment. Current Directions in Psychological Science, 12(4), 105-109.

Cialdini, R. B., Kallgren, C. A. ve Reno, R. R. (1991). A focus theory of normative conduct: A theoretical refinement and reevaluation of the role of norms in human behavior. L. Berkowitz (Ed.), Advances in experimental social psychology içinde (s. 201-234). San Diego, CA: Academic Press.

Cialdini, R. B., Reno, R. R. ve Kallgren, C. A. (1990). A focus theory of normative conduct: Recycling the concept of norms to reduce littering in public places. Journal of Personality and Social Psychology, 58(6), 1015-1026.

Cohen, J., Cohen, P., West, S. G. ve Aiken, L. S. (2003). Applied multiple correlation/regression analysis for the behavioral sciences. England: Taylor \& Francis.

Cooper, R., DeJong, D. V., Forsythe, R., \& Ross, T. W. (1996). Cooperation without reputation: experimental evidence from prisoner's dilemma games. Games and Economic Behavior, 12(2), 187-218.

Crowe, E. ve Higgins, E.T. (1997). Regulatory focus and strategic inclinations: Promotion and prevention in decision-making. Organizational Behavior and Human Decision Processes, 69(2), $117-132$.

Çalık, T., Özbay, Y., Özer, A., Kurt, T. ve Kandemir, M. (2009). İlköğretim okulu öğrencilerinin zorbalık statülerinin okul iklimi, prososyal davranışlar, temel ihtiyaçlar ve cinsiyet değişkenlerine göre incelenmesi. Kuram ve Uygulamada Eğitim Yönetimi, 60(60), 555-576.

Das, E., Kerkhof, P. ve Kuiper, J. (2008). Improving the effectiveness of fundraising messages: The impact of charity goal attainment, message framing, and evidence on persuasion. Journal of Applied Communication Research, 36(2), 161-175.

Davis, J. J. (1995). The effects of message framing on response to environmental communications. Journalism \& Mass Communication Quarterly, 72(2), 285-299.

Dawes, R. M. (1980). Social dilemmas. Annual Review of Psychology, 31(1), 169-193.

De Cremer, D. ve Van Lange, P. A. M. (2001). Why prosocials exhibit greater cooperation than proselfs: The roles of social responsibility and reciprocity. European Journal of Personality, 15(1), 5-18.

Dovidio, J. F. (1984). Helping behavior and altruism: An empirical and conceptual overview. Advances in Experimental Social Psychology, 17, 361-427.

Eisenberg, N. (1991). Meta-analytic contributions to the literature on prosocial behavior. Personality and Social Psychology Bulletin, 17(3), 273-282.

Eisenberg, N. ve Fabes, R. A. (1991). Prosocial behavior and empathy: A multimethod developmental perspective. M. S. Clark (Ed.), Prosocial behavior içinde (s. 34-61). Sage Publications, Inc.

Eisenberg, N. ve Fabes, R. A. (1998). Prosocial development. W. Damon ve N. Eisenberg (Ed.), 
Handbook of child psychology: Social, emotional, and personality development içinde (s. 701778). John Wiley \& Sons, Inc.

Elliott, C. S. ve Hayward, D. M. (1998). The expanding definition of framing and its particular impact on economic experimentation. The Journal of Socio-Economics, 27(2), 229-243.

Fairbairn, C. E. ve Sayette, M. A. (2013). The effect of alcohol on emotional inertia: A test of alcohol myopia. Journal of Abnormal Psychology, 122(3), 770-781.

Fehr, E. ve Gächter, S. (2002). Altruistic punishment in humans. Nature, 415(6868), 137-140.

Förster, J., Higgins, E. T. ve Bianco, A. T. (2003). Speed/accuracy decisions in task performance: Built-in trade-off or separate strategic concerns?. Organizational Behavior and Human Decision Processes, 90(1), 148-164.

Friedman, R. S. ve Förster, J. (2001). The effects of promotion and prevention cues on creativity. Journal of Personality and Social Psychology, 81(6), 1001-1013.

Gaertner, S. L., Dovidio, J. F., Rust, M. C., Nier, J. A., Banker, B. S., Ward, C. M., ... ve Houlette, M. (1999). Reducing intergroup bias: Elements of intergroup cooperation. Journal of Personality and Social Psychology, 76(3), 388.

Gächter, S. ve Fehr, E. (1999). Collective action as a social exchange. Journal of Economic Behavior \& Organization, 39(4), 341-369.

Gino, F. ve Margolis, J. D. (2011). Bringing ethics into focus: How regulatory focus and risk preferences influence (un)ethical behavior. Organizational Behavior and Human Decision Processes, 115(2), 145-156.

Godinho, C. A., Updegraff, J. A., Alvarez, M. J. ve Lima, M. L. (2017). When is congruency helpful? Interactive effects of frame, motivational orientation, and perceived message quality on fruit and vegetable consumption. Journal of health communication, 22(12), 942-950.

Hayward, R. D. ve Kemmelmeier, M. (2007). How competition is viewed across cultures: A test of four theories. Cross-Cultural Research, 41(4), 364-395.

Herrmann, B., Thöni, C. ve Gächter, S. (2008). Antisocial punishment across societies. Science, 319(5868), 1362-1367.

Higgins, E. T. (1997). Beyond pleasure and pain. American Psychologist, 52(12), 1280-1300.

Higgins, E. T. (1998). Promotion and prevention: Regulatory focus as a motivational principle. M.P. Zanna (Ed.), Advances in experimental social psychology içinde (s. 1-46). New York: Academic Press.

Higgins, E. T. (2012). Regulatory focus theory. Handbook of theories of social psychology. London: Sage London

Higgins, E. T., Friedman, R. S., Harlow, R. E., Idson, L. C., Ayduk, O. N. ve Taylor, A. (2001). Achievement orientations from subjective histories of success: Promotion pride versus prevention pride. European Journal of Social Psychology, 31(1), 3-23.

Higgins, E. T. ve Spiegel, S. (2004). Promotion and prevention strategies for self-regulation: A motivated cognition perspective. R. F. Baumeister ve K. D. Vohs (Ed), Handbook of self-regulation: Research, theory, and applications içinde (s. 171-187). New York, NY: Guilford Press.

Idson, L. C., Liberman, N. ve Higgins, E. T. (2000). Distinguishing gains from nonlosses and losses from nongains: A regulatory focus perspective on hedonic intensity. Journal of Experimental Social Psychology, 36(3), 252-274.

Israel, S., Lerer, E., Shalev, I., Uzefovsky, F., Riebold, M., Laiba, E., ... ve Ebstein, R. P. (2009). The oxytocin receptor (OXTR) contributes to prosocial fund allocations in the dictator game and the social value orientations task. PloS One, 4(5), 1-10. 
Kallgren, C. A., Reno, R. R. ve Cialdini, R. B. (2000). A focus theory of normative conduct: When norms do and do not affect behavior. Personality and Social Psychology Bulletin, 26(8), $1002-1012$.

Karagonlar, G. ve Kuhlman, D. M. (2013). The role of social value orientation in response to an unfair offer in the ultimatum game. Organizational Behavior and Human Decision Processes, 120(2), 228-239.

Karagonlar, G. ve Neves, P. (2020). No more Mr. Nice Guy: Social value orientation and abusive supervision. Journal of Managerial Psychology, 35(2), 85-99.

Keller, J. ve Pfattheicher, S. (2011). Vigilant self-regulation, cues of being watched and cooperativeness. European Journal of Personality, 25(5), 363-372.

Kelley, H. H. ve Stahelski, A. J. (1970). Social interaction basis of cooperators' and competitors' beliefs about others. Journal of Personality and Social Psychology, 16(1), 66-91.

Kelley, H. H. ve Thibaut, J. W. (1978). Interpersonal relations: A theory of interdependence. New York: Wiley-Interscience.

Kiyonari, T., Yamagishi, T., Cook, K. S. ve Cheshire, C. (2006). Does trust beget trustworthiness? Trust and trustworthiness in two games and two cultures: A research note. Social Psychology Quarterly, 69(3), 270-283.

Kollock, P. (1998). Social dilemmas: The anatomy of cooperation. Annual Review of Sociology, 24(1), $183-214$.

Köbis, N. C., Van Prooijen, J. W., Righetti, F. ve Van Lange, P. A. (2015). “Who doesn't?”- -The impact of descriptive norms on corruption. PloS ONE, 10(6), e 0131830.

Kuhlman, D. M., Camac, C. R. ve Cunha, D. A. (1986). Individual differences in social orientation. H. Wilke, D. Messick ve C. Rutte (Ed.), Experimental social dilemmas içinde (s. 151-176). New York: Verlag Peter Lang.

Kuhlman, D. M. ve Marshello, A. F. (1975). Individual differences in game motivation as moderators of preprogrammed strategy effects in prisoner's dilemma. Journal of Personality and Social Psychology, 32(5), 922-931.

Kuhlman, D. M. ve Wimberley, D. L. (1976). Expectations of choice behavior held by cooperators, competitors, and individualists across four classes of experimental games. Journal of Personality and Social Psychology, 34(1), 69-81.

Latané, B. ve Darley, J. M. (1970). The unresponsive bystander: Why doesn't he help? New York: Appleton-Century-Crofts.

Liebrand, W. B. (1984). The Effect of social motives, communication and group size on behaviour in an n-person multi-stage mixed-motive game. European Journal of Social Psychology, 14(3), 239-264.

Liebrand, W. B. ve McClintock, C. G. (1988). The ring measure of social values: A computerized procedure for assessing individual differences in information processing and social value orientation. European Journal of Personality, 2(3), 217-230.

Maner, J. K., DeWall, C. N., Baumeister, R. F. ve Schaller, M. (2007). Does social exclusion motivate interpersonal reconnection? Resolving the "porcupine problem.". Journal of Personality and Social Psychology, 92(1), 42-55.

Maner, J. K., Luce, C. L., Neuberg, S. L., Cialdini, R. B., Brown, S. ve Sagarin, B. J. (2002). The effects of perspective taking on motivations for helping: Still no evidence for altruism. Personality and Social Psychology Bulletin, 28(11), 1601-1610.

Martinsson, P., Villegas-Palacio, C. ve Wollbrant, C. (2015). Cooperation and social classes: Evidence from Colombia. Social Choice and Welfare, 45(4), 829-848. 
Mayer, J. D. ve Gaschke, Y. N. (1988). The experience and meta-experience of mood. Journal of Personality and Social Psychology, 55(1), 102-111.

McClintock, C. G. ve Liebrand, W. B. (1988). Role of interdependence structure, individual value orientation, and another's strategy in social decision making: A transformational analysis. Journal of Personality and Social Psychology, 55(3), 396-409.

Messick, D. M. ve McClintock, C. G. (1968). Motivational bases of choice in experimental games. Journal of Experimental Social Psychology, 4(1), 1-25.

Murphy, R. O., Ackermann, K. A. ve Handgraaf, M. (2011). Measuring social value orientation. Judgment and Decision Making, 6(8), 771-781.

Nowak, M. A. ve Sigmund, K. (2005). Evolution of indirect reciprocity. Nature, 437(7063), 1291-1298.

Omoto, A. M. ve Snyder, M. (1995). Sustained helping without obligation: Motivation, longevity of service, and perceived attitude change among AIDS volunteers. Journal of Personality and Social Psychology, 68(4), 671.

Omoto, A. M. ve Snyder, M. (2002). Considerations of community: The context and process of volunteerism. American Behavioral Scientist, 45(5), 846-867.

Ortmann, A. ve Tichy, L. K. (1999). Gender differences in the laboratory: Evidence from prisoner's dilemma games. Journal of Economic Behavior \& Organization, 39(3), 327-339.

Parks, C. D., Joireman, J. ve Van Lange, P. A. (2013). Cooperation, trust, and antagonism: How public goods are promoted. Psychological Science in the Public Interest, 14(3), 119-165.

Penner, L. A., Dovidio, J. F., Piliavin, J. A. ve Schroeder, D. A. (2005). Prosocial behavior: Multilevel perspectives. Annual Review of Psychology, 56, 365-392.

Pfattheicher, S. ve Keller, J. (2013). Vigilant self-regulation and costly punishment in public goods situations. European Journal of Personality, 27(4), 346-354.

Pham, M. T. ve Avnet, T. (2009). Contingent reliance on the affect heuristic as a function of regulatory focus. Organizational Behavior and Human Decision Processes, 108(2), 267-278.

Piff, P. K., Kraus, M. W., Côté, S., Cheng, B. H. ve Keltner, D. (2010). Having less, giving more: The influence of social class on prosocial behavior. Journal of Personality and Social Psychology, 99(5), 771-784.

Piliavin, J. A. ve Charng, H. W. (1990). Altruism: A review of recent theory and research. Annual Review of Sociology, 16(1), 27-65.

Piliavin, J. A., Dovidio, J. F., Gaertner, S. L. ve Clark, R. D. III. (1981). Emergency intervention. New York: Academic Press.

Pletzer, J. L., Balliet, D., Joireman, J., Kuhlman, D. M., Voelpel, S. C. ve Van Lange, P. A. (2018). Social value orientation, expectations, and cooperation in social dilemmas: A meta-analysis. European Journal of Personality, 32(1), 62-83.

Pruitt, D. G. ve Kimmel, M. J. (1977). Twenty years of experimental gaming: Critique, synthesis, and suggestions for the future. Annual Review of Psychology, 28(1), 363-392.

Rothman, A. J. ve Salovey, P. (1997). Shaping perceptions to motivate healthy behavior: The role of message framing. Psychological Bulletin, 121(1), 3-19.

Schwartz, S. H. ve Howard, J. A. (1982). Helping and cooperation: A self-based motivational model. V. J. Derlega, J. Grzelak (Ed.), Cooperation and helping behavior içinde (s. 327-353). New York: Academic press.

Seguino, S., Stevens, T. ve Lutz, M. (1996). Gender and cooperative behavior: Economic man rides alone. Feminist Economics, 2(1), 1-21.

Sell, J. (1997). Gender, strategies, and contributions to public goods. Social Psychology Quarterly 60, 
$252-65$.

Simpson, B. (2003). Sex, fear, and greed: A social dilemma analysis of gender and cooperation. Social Forces, 82(1), 35-52.

Staub, E. 2002. Emergency helping, genocidal violence, and the evolution of responsibility and altruism in children. R.J. Davidson ve A. Harrington (Ed)., Visions of compassion: Western scientists and Tibetan buddhists examine human nature içinde (s. 165-81). London: Oxford Univ. Press

Staunton, M., Louis, W. R., Smith, J. R., Terry, D. J. ve McDonald, R. I. (2014). How negative descriptive norms for healthy eating undermine the effects of positive injunctive norms. Journal of Applied Social Psychology, 44(4), 319-330.

Stockard, J., Van De Kragt, A. J. ve Dodge, P. J. (1988). Gender roles and behavior in social dilemmas: Are there sex differences in cooperation and in its justification?. Social Psychology Quarterly, 51(2), 154-163.

Tice, D. M., Bratslavsky, E. ve Baumeister, R. F. (2001). Emotional distress regulation takes precedence over impulse control: If you feel bad, do it!. Journal of Personality and Social Psychology, 80(1), 53-67.

Tversky, A. ve Kahneman, D. (1981). The framing of decisions and the psychology of choice. Science, 211(4481), 453-458.

Tversky, A. ve Kahneman, D. (1986). Rational choice and the framing of decisions. The Journal of Business, 59(1), 251-278.

Uskul, A. K., Sherman, D. K. ve Fitzgibbon, J. (2009). The cultural congruency effect: Culture, regulatory focus, and the effectiveness of gain-vs. loss-framed health messages. Journal of Experimental Social Psychology, 45(3), 535-541.

Van Andel, C. E., Tybur, J. M. ve Van Lange, P. A. (2016). Donor registration, college major, and prosociality: Differences among students of economics, medicine and psychology. Personality and Individual Differences, 94, 277-283.

Van Baaren, R. B., Holland, R. W., Kawakami, K. ve Van Knippenberg, A. (2004). Mimicry and prosocial behavior. Psychological science, 15(1), 71-74.

Van Lange, P. A. M. (1999). The Pursuit of joint outcomes and equality in outcomes: An integrative model of social value orientation. Journal of Personality and Social Psychology, 77(2), 337-349.

Van Lange, P. A. M., Bekkers, R., Schuyt, T. N. M. ve Van Vugt, M. V. (2007). From games to giving: Social value orientation predicts donations to noble causes. Basic and Applied Social Psychology, 29(4), 375-384.

Van Lange, P. A. M., De Bruin, E., Otten, W. ve Joireman, J. A. (1997). Development of prosocial, individualistic, and competitive orientations: Theory and preliminary evidence. Journal of Personality and Social Psychology, 73(4), 733-746.

Van Lange, P. A. M., Joireman, J., Parks, C. D. ve Van Dijk, E. (2013). The psychology of social dilemmas: A review. Organizational Behavior and Human Decision Processes, 120(2), 125-141.

Van Lange, P. A. M. ve Kuhlman, D. M. (1994). Social value orientations and impressions of partner's honesty and intelligence: A test of the might versus morality effect. Journal of Personality and Social Psychology, 67(1), 126-141.

Van Lange, P. A. M. ve Rusbult, C. E. (2012). Interdependence theory. P. A. M. Van Lange, A. W. Kruglanski ve E. T. Higgins (Ed.), Handbook of theories of social psychology içinde (s. 251-272). London: Sage London.

Vugt, M. V., Cremer, D. D. ve Janssen, D. P. (2007). Gender differences in cooperation and competition: The male-warrior hypothesis. Psychological science, 18(1), 19-23. 
Van Vugt, V. M., Meertens, R. M. ve Van Lange, P. A. M. (1995). Car versus public transportation? The role of social value orientations in a real-life social dilemma. Journal of Applied Social Psychology, 25(3), 258-278.

Wan, E. W., Hong, J. ve Sternthal, B. (2009). The effect of regulatory orientation and decision strategy on brand judgments. Journal of Consumer Research, 35(6), 1026-1038.

Yaban, H. (2017). Ergenler ve beliren yetişkinlerde sosyal değer yöneliminin gelişimsel, sosyal-bilişsel ve bağlamsal bir model çerçevesinde incelenmesi (Doktora Tezi). Hacettepe Üniversitesi Sosyal Bilimler Enstitüsü, Ankara, Türkiye.

Yamagishi, T., Mifune, N., Li, Y., Shinada, M., Hashimoto, H., Horita, Y., ... ve Takagishi, H. (2013). Is behavioral pro-sociality game-specific? Pro-social preference and expectations of pro-sociality. Organizational Behavior and Human Decision Processes, 120(2), 260-271.

Yener, S. (2017). Psikolojik rahatlık algısının işgören sesliliği ve takım işbirliği arasındaki ilişkide aracı değişken rolü. Dokuz Eylül Üniversitesi Sosyal Bilimler Enstitüsü Dergisi, 19(2), 187-204.

Yeşiltaş, M., Kanten, P. ve Sormaz, Ü. (2013). Otantik liderlik tarzının prososyal hizmet davranışları üzerindeki etkisi: Konaklama işletmelerine yönelik bir uygulama. Istanbul University Journal of the School of Business Administration, 42(2), 333-350. 
